\title{
For Reference
}

NOT TO BE TAKEN FROM THIS ROOM

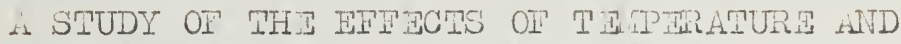

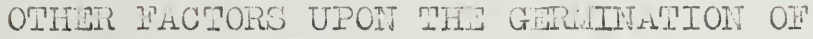

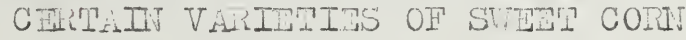

\section{T. Torfason}

3

Department of Plant Science

University of Alberta

$$
\text { April, } 1952
$$

\section{Thes is}

1952

\#40 


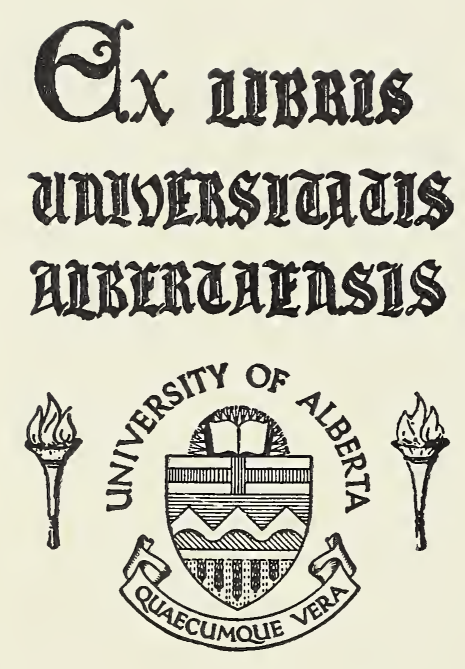




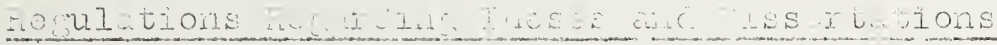

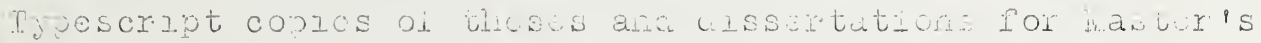

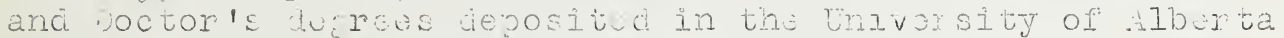

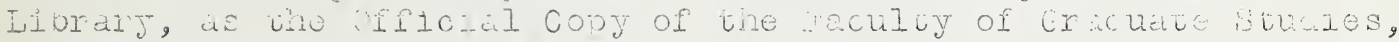

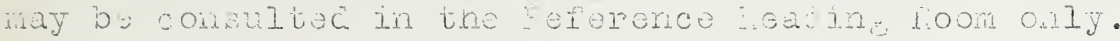

A sucon cooy is on doposit in the Departinent under whose slipervistun tize worli vés cone. Sone "eparirents aie willine to

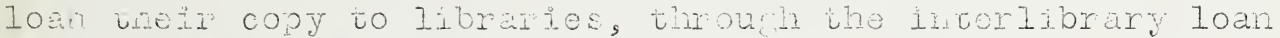
service ol the tniversity of alberta library.

These theses anc dissertivions are to os lisect only with due regarc to priority rights of the author. ritten pormissior of the author and of the peparbent mist be ouchinac thouh tile University of Alberta Library when extenciod passases are used. Whor permission has been gronted, credit must appear in the published work.

This thesis or cissertution has been used in accordance with the above regulations by the pesons listed below. The borrowing library is obligated to secure ihe sinaure of each user.

Please sín velow:

Date Signature Institution 
Digitized by the Internet Archive in 2017 with funding from University of Alberta Libraries 


\section{ABSTRACT}

A series of trials were conducted during 1950 and 1951 to study the efI'ects oI temperature, as wel1 as the efiects oI the nature oI the germinating medium and of the auration of exposure, upon the germination or three open-pollinated and one hybrid varieties oI sweet com. The results indicated that germination oI sweet corn seed was seriousiy inhibited by temperatures of $10^{\circ} \mathrm{C}$. or Iower, with no apparent dirierence between the eriects or the Iower temperatures. Germination in soli was lower than in sterile vermicuifte, particularly at low temperatures, indicating that soil pathogens play an important role in limiting germination in cold soil. The duration oI exposure was an important Iimiting Iactor only at the lower temperatures. Although signiticant varietal dirierences were observed, they could not be attributed to any differences in cola resistance, but must be considered as being related to the viability, and possibly to the maturity, of the individual seed lots used. 

THE UNIVERSITY OF AIBERTA

A STUDY OF THE ETTECTS OF TEIPERATURE AND OTHER FACTORS UPON THE GERIIINATION OF CERTAIN VARIMTIES OF SWEET CORN

\section{A DISSERTATION}

SUBNITTED TO THE SCHOOL OF GRADUATY STUDIRS

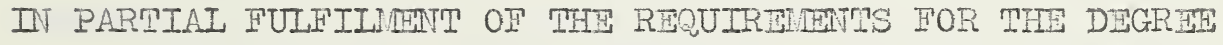
OF MASTHR OF SCIHINCE

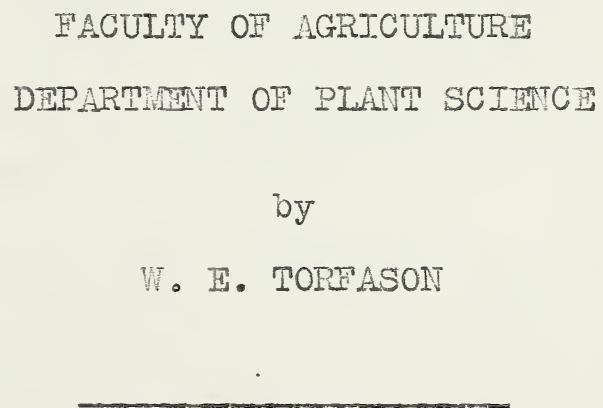

FEIIONTON, AIBTIRTA

April, 1952 



\section{PABIE OP CONDWND}

Introduction $\ldots \ldots \ldots \ldots \ldots \ldots \ldots \ldots \ldots \ldots \ldots \ldots \ldots \ldots \ldots \ldots$

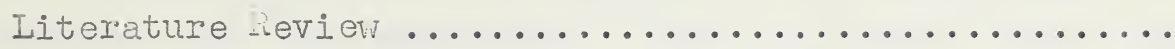

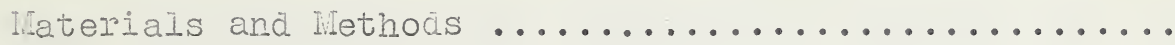

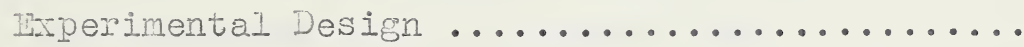

Ilethods of collecting Data ..............

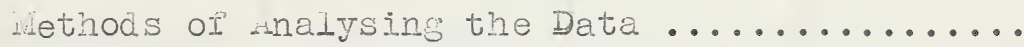

Climatic Intiuences $\ldots \ldots \ldots \ldots \ldots \ldots \ldots \ldots$

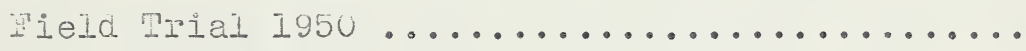

Greenhouse Lrial $1950-51 \ldots \ldots \ldots \ldots \ldots \ldots \ldots$

Greenhouse Mrial - PalI $1951 \ldots \ldots \ldots \ldots \ldots$

Discussion of Results

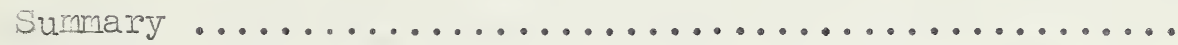

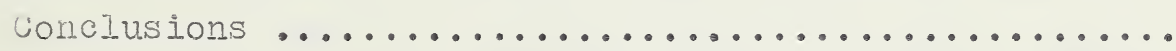

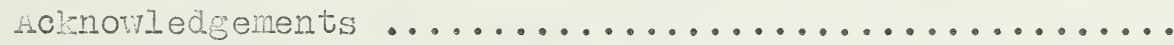

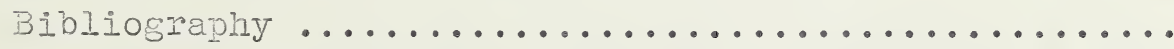

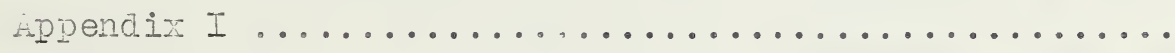

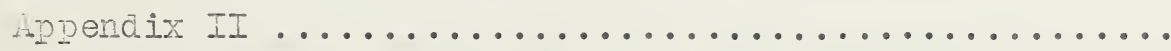

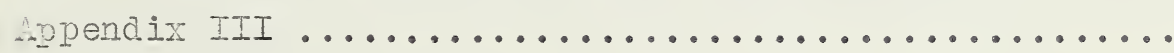

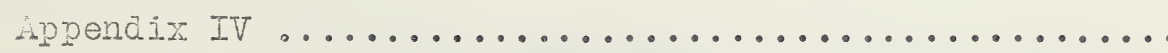





\section{IITRODUCTION}

Sweet corn is one of the most important oI the canning crops grown in Southern Alberta. The acreage producing sweet corn is increasing annualdy, and is expected to increase sharply with the completion or the St. Mary's Irrigation Development. It has also become increasingly apparent that, in the near Iuture, more canneries will be erected and go into production, in the area served by irrigation. In addition, the canning firms are considering the installation oI quick freezing equipment to satisiy the ever increasing demand for tresh frozen Iruit and vegetabie products. This part of the processing industry is still in its infancy and will, as it expands, require the production of an increasing volume of sweet corn.

Growers and research workers alike have orten observed that stands of sweet corn are poor in seasons when cola, wet soil conditions prevail during the gemination period. These observations have led canning company fieldmen, farmers, and research workers to ask, Why should this be so?" "Is the ability or the seed to germinate inhibited or destroyed by low soil temperatures?" "Or, are attacks by soil pathogens, upon the elongating coleoptiles, responsible for the reduction of the final stands in the Iield?"

The species Zea mays $L$. is known generally to be a "warm season" plant, and thus its development is best under condi-

* This term, a.s used in this thesis, refers to soil-borne pathogens. 

tions of high summer temperatures. The reasons underlying poor germination at low temperatures are, however, little understood. The project, reported herein, was initiated to study the effects of exposure to low soil temperatures, in several media, upon the germination of certain varieties of sweet corn. It was hoped that the information gained would be userul in answering the above questions.

\section{IITHRATURP REVIYWV}

Heyer and Anderson (15) detine germination of seeds as the resunption of active growth on the part of the embryo, resulting in the rupture of the seed coats and the emergence of the joung plants. Environmental conditions conducive to normal germination include adequate moisture and oxygen, as weIl as a "suitable" temperature. The germination is also aftected by varietal differences in vigor and speed of germination, by inherent difterences in embryo development, by the viabiifty of the seed itself, and by the presence of insects and pathogenic micro-organisms in the soil. The above authors observe that the initiation of growth is essentially enzymatic in nature. lioisture and ternerature are, therefore, important factors since both are required in optimun degree for the activation of enzymes. Seeds of most species of plants will geminate over a wide range of temperatures but naximum germination is obtained at some intemediate (optimurn) temperature. Heyer and Anderson (15) state 

that com will gerninate through a range of terperatures from bo or $10^{\circ} \mathrm{C}$. to $45^{\circ} \mathrm{C}$, with an optimur oi aprozinately $50^{\circ} \mathrm{C}$, whereas wheat has a range from $0^{\circ} \mathrm{C}$ to $35^{\circ} \mathrm{C}$. With an optimum between $15^{\circ}$ and $20^{\circ} \mathrm{C}$.

Tarly vorl on the eftect or temperature on the gernination of menbers of the grass Ianily were conciucted on wheat, oats, and barley - species which are known to tolerate relatively low soil temperatures. Investigations, conducted by Vilson (2己), Wilson and Hottes (23), and BelI (I), all conclude that small grain cereals will germinate satisfactorily at low temperatures $\left(0^{0}\right.$ to $\left.10^{\circ} \mathrm{C}.\right)$ with an optimum near $15^{\circ}$ to $20^{\circ}$. Wilson and Hottes (23) observed that above the optimum temperature the decrease in percentage germination of wheat was accompanied by an increased percentage of damage due to İungal activity. Cofiman, as cited by Wilson and Hottes(23), observed that small grains will germinate at the temperature or nelting ice.

Jones (II) studied the erfect of temperature on the germination of rice which, like sweet corn, is a warm season crop. He observed that some varieties germinated quite well arter exposure in a moist condition to temperatures of $0^{\circ}, 2^{\circ}$, and $5^{\circ} \mathrm{C}$. for periods up to 36 days:

Robbins and Petsch (18) studied the relationship oI moisture content oI the seeds and high temperature to the germination of corn (flint and dent varieties vere used). They observed that as the moisture content of the seed increased the percentage germination lowered markedy under low or high temperature 

conditions. This is shown graphically in Figure 1. Low temperature data were obtained Irom the studies of Kiesselbach and Ratcliff as reported by Robbins and Petsch (18). The low temperature data show a similar trend to that of high temperature data.

Haskell (4) exposed selected Ilat and round seeds of each of six single-cross hybrids and one double-cross sweet corn hybria to a temperature of $10^{\circ}$. Ior eight days. Germination was completed in a warm greenhouse. Although round seeds were heavier than the Ilat seeds there was no significant difference between gemination rates. He suggested a difrerential behavior between hybrids.

Haskell (5) seeded live inbred lines of sweet corn in flats or rield soil, recently under com. One series of lats was placed in a cold room at $10^{\circ} \mathrm{C}$, and the other series in another cola room at $5^{\circ} \mathrm{C}$. The soil was kept moist as required. At intervals of Irom two to thirty-two days flats were removed. from the cold rooms and germination rates were detemined in a warm greenhouse. He observed that germination percentages were lower ror the $10^{\circ} \mathrm{C}$. temperature than for the lower temperature, and that the percentage became lower as the period or exposure lengthened regardiess of geminating temperature. He states that the difference between the efrects of the two temperatures suggest that the loss in germinability is due in part to cold, and in part to the penetration or soil pathogens into the slowly developing seedling. He believes the pathogens to be partiy inhibited 


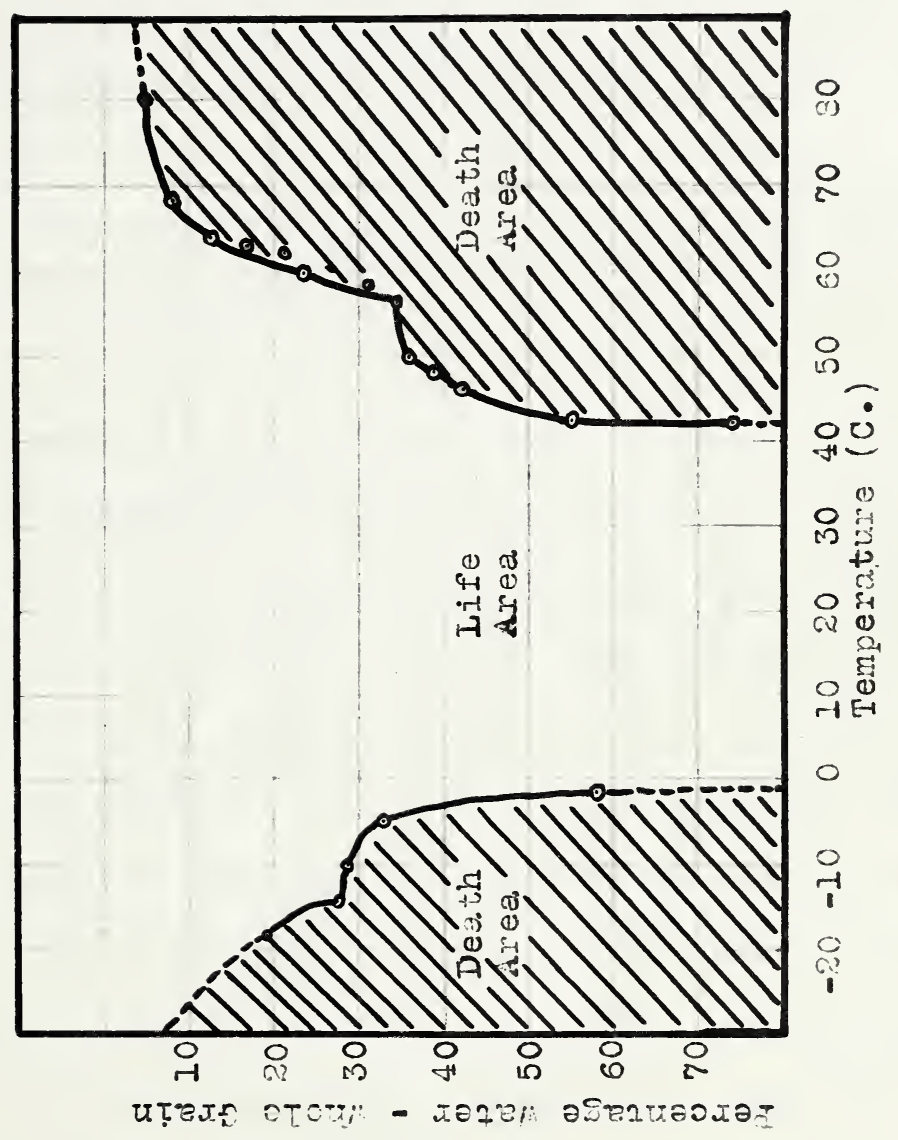

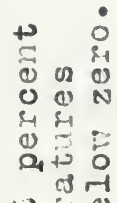

(i) $\begin{array}{ll}-1 & 0 \\ 0 & 0\end{array}$

-

तो की 0

ort to s

\& :

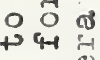

요 $\Omega$

\& 14

भi 0

7

() 0 क

i

बै थ

म्ट

त) 020

(3)

(1) भी

2

वें

† ⿷匚

ㅇํㅇ

,

담

t3

궁

o 0 A

म न

c)

to 0 त०

ता लिख

है को 12

$\begin{array}{lll}4-1 & \cup 2 & \sim\end{array}$

० द्न 0 च

दी तो ?

O \& (1)

न 4 हो 0

(1) द्व

मो ल क्र

a) 000

1) 0

$+\stackrel{N}{+} N$

त

(1) 3

$\therefore A>0$

Fis 0 का 

at $5^{\circ} \mathrm{C}$. , and, theretore, more active at $10^{\circ} \mathrm{C}$. In conclusion, he states that the $5^{\circ} \mathrm{C}$. treatment gives a truer picture of the resistance of the inbreds to cold, but that the $10^{\circ} \mathrm{C}$. treatment is more critical and selective to other detrimental influences.

Haskell (6) continuing his investigations, soaked the seeds ot four sweet corn inbreds in water for periods varying from 0 to 60 hours, and then exposed them for eight days at temperatures of $5^{\circ} \mathrm{C}$, and $15^{\circ} \mathrm{C}$. He noticed that pre-soaking the seeds aid not alter their behavior to cold treatment although germination at the higher temperature was more rapid alter presoaking。

Haskell (7) seeāea Iive inbred lines ol sweet corn and one strain of hybrid dent corn in sand and soil, and exposed. them to temperatures of $5^{\circ} \mathrm{C}$. and $10^{\circ} \mathrm{C}$. For varying periods of time. Germination was completed in a warm greenhouse. From the results the investigator made the rollowing conclusions: (a) The longer the period or exposure, the greater was the number of pre-energea seealings kilied ort; (b) Strains reacted. dilterentiy to cold treatment; (c) Genetical constitution, temperature, exposure tine, and the nature or the geminating mediun all significantly aIrect the Iinal germination; and (a) As an aid to plant breeding, the controlled cold treatment oliers a suitable method for artifically selecting hardier strains of sweet corn.

Haskell (8), in a Iield trial, seeded six varieties at 28 day intervals beginning on Harch 1 . He observed that as the 
sowing dates became later the interval to towering became shorter, and that maturity was directly proportional to Ilowering time. The size oI ears was not materially arfected by sowing date, although later sowings gave ears with higher numbers oI rows. The earlier sowings produced plants which were shorter, with more tiliers, and which produced slightIy higher plant yields. Haskell and Singleton (9) seeded a number of inbred. lines and hybrids ot sweet and rield corn in ilats which were exposed to $10^{\circ} \mathrm{C}$. for 32 days, and then transierred to a warn greenhouse Ior completion of germination. The same lines vere seeded. outdoors in early April. In all cases, outdoor gemination percentages were much higher than those from the cold rooms. Sweet corn lines were as cold hardy as the lines of Iield corn. The fiela corn hybrias geminated better than their parent lines, iliustrating a possible eifect of heterosis on cold hardiness. They conclude that the cold treatments can be used advantageously to supplement field trials for cold hardiness.

Wather and Haskel1 (I4) observed, in England, that corn varieties geminate allierently accoraing to date oI seeding. They selected haray plants which survived eariy March sowing and, as the selected lines becane nardier, selections weje made from February sowings. Two sweet com varieties and one dent variety increased their ability to germinate trom February sovings, while Peruvian derivatives of sweet corn, used in the test, dia not. The selected Iines are to be tested tor combining ability, and used as a basis Ior obtaining cold hardy sweet corn hybrids tor the British IsIes. 

PinnelI (17), on the basis oI IU years' laboratory and Iield tests, concluded that double-cross corn hybrias germinated best at low temperatures, Hollowed by single-cross hybrids and inbred lines in order. He observed that wide ditferences in the germination or inbred lines appeared to be heritable in crosses, and that the remale parent was more important than the maLe parent in determining seeding stands oI single- and double-cross hybrids, indicating that this nay be aue to a Iorm of cytoplasmic inheritance.

Vander Meulen and Henke (21) Iound cold testing of corn to be valuable in determining the eltects or Iungicides used Ior seed treatment. Fungicides, at best, protect good seed irom destructive pathogens when germination is delayed due to cold, wet soils. Cold testing also emphasizes the importance of proper methods of seed production, handing, processing, and storage since mechanical aamage would result in poor gemination under adverse growing conditions by permitting soil pathogens to penetrate the seed coat easily.

Dickson and Holbert (2) found that corn seedings grown at Iov temperatures $\left(80-20^{\circ} 0\right.$.) are Low in soluble carbohydrate building substances, and that the cell walls are composed largely of pentosan yielding substances. On the other hand, seedings grom at high temperatures (2400, and above) have large reserves of soluble carbohydrate building substances, and the cell walls are composed of cellulose impregnated with suberin. The latter are highly resistant to Iungal penetration, while in the 

former fungi are able to obtain nourishment directly rrom the cell wall and thus gain entry into the seeding.

Tatum and Zuber (20) reviewed the separate works of Meyer, Koehler, and Tatum, all of whom observed that germination oI corn seed was reduced when any amount of pericarp damage was present. Tatum had believed that minor injuries over the germ were as serious as more obvious damage to other parts of the kernel. Tatum and Zuber (20) found that low temperature alone did not decrease gemination in sterilized soil, indicating that soil pathogens were responsible for the reduction in germination. They emphasized the need for more careful handing of the seed.

Lehenbauer (12) held corn seedings at constant temperatures and concluded that the minimum growth temperature for corn was near $12^{\circ} \mathrm{C}$. to $140^{\circ}$.

Mrwin (3) observed that sweet corn seed germinated prompty when the soil temperature is approximately I2.7800. $\left(55^{\circ} \mathrm{F}.\right)$, provided that other conditions vere optimum.

Rush and Neal (19) of Wisconsin, obtained corn seed Which had. been harvested at 10 day intervals, and exposed it to a temperature of $10^{\circ} \mathrm{C}$. in soil ror 14 days. They round that stands improved with the increase in maturity of the seed. On the other hand, seed harvested after a rrost gave signiticantly lower germination under cold test conditions than untrosted seed which was not as advanced in maturity. These workers concluded that seed coat injury did not appear to be of major significance in deter- 

mining the stands of com at low temperatures, and that Arasan treated seed gave better stands than untreated seed or the same maturity.

Magoon and Culpepper (13), atter a series ot experiments conducted at diflerent locations throughout the United States, concluded that the minimum air temperature required tor development of sweet corn fell within a range of $50^{\circ} \mathrm{F}$. to $60^{\mathrm{F}}$. $\left(10^{\circ} \mathrm{C}\right.$. to $\left.15.6^{\circ} \mathrm{C}.\right)$ and that this requirement varied with varieties and with strains within varieties. These investigators observed that the minimum soil temperature I’eII approximately $5 \mathrm{OF}_{\mathrm{H}}\left(2.78^{\circ} \mathrm{C}.\right)$ lower than the mininum air temperature.

Nortimer (16), in studying the germinating ability or 36 reciprocal single crosses under adverse conditions tound that 55.5 per cent of the single crosses showed significant difIerences between reciprocals, with the maternal parent playing the primary role in detemining the diflerences. This agrees with the conclusions or Pinnell (17), already cited.

\section{MATERTAIS AND INETHODS}

Four factors relating to the germination of sweet corn were considered in this study. These are reviewed brietly in the following paragraphs.

(1) Temperature

Controlled temperature chambers were available at the Science Service Laboratories, Iethbridge, Alberta for the fiela 
trial carried out in 1950, and at the Food Processing Laboratory of the Experimental Station, Lethbriage, Alberta for the field and greenhouse trials undertaken in 1951. In both units, temperatures of $5^{\circ} \mathrm{C} ., 10^{\circ} \mathrm{C}$, and $15^{\circ} \mathrm{C}$. were maintained throughout the period or exposure. At the University of Alberta during the winter of 1950-51 the above temperatures could not be duplicated, and the trial was carried out using temperatures of $35^{\circ} \mathrm{F} .\left(1.70^{\circ} \mathrm{C}\right)$, $50^{\circ} \mathrm{F} .\left(10^{\circ} \mathrm{C}.\right)$, and $65^{\circ} \mathrm{F} \cdot\left(18.3^{\circ} \mathrm{C}.\right)$.

(2) Germinating ledium

The seed was som in 5 different nedia, (a) Lethbridge brown silt loam from the horticultural area of the Experimental Station, (b) Parkland black loaikfrom the Parkland. Farm of the University of Alberta, Ednonton, Alberta, and (c) Vermiculite, an inert mineral substance (heat expanded particles of mical sold under the trade narne of "Zonolite". Neither of the soils had been used for the growing or corn tor a nuraber of years.

(3) Duration of Dxposure

The seed was exposed in each of the above nedia and at each of the above temperatures Ior periods of IO, 20 , and 50 days duration.

(4) Varieties

Wach of 3 open-pollinated sweet corn varieties (Altagold, Dorinny, and Golden Early Market) and I sweet corn hybrid (Carrelcross) were subjected to all combinations of the above factors. 

In the controlled temperature chambers, the seed was sown in the rlats and covered with approximately one inch of the appropriate medium. The media were kept noist as required. Seeding was done at 10 day intervals so that all exposure periods would be completed at the same time, e.g. the 30 day exposure was som rirst, Iollowed 10 days later by the 20 day exposure, etc.

After the exposures were completed the fllats were removed Iron the controlled temperature chambers and transferred. to the field or to a greenhouse for completion of germination. When transferred to the riela, the seeds were renoved from the flats and set into the soil at approximately the same depth as they were in the flats.

\section{Experimental Design}

The trials were set up in a split plot design, with 4 replications. Wach replication consisted of 9 whole plots (each llat made up a single whole plot) made up or alI combinations of the 3 temperatures and the 3 media, as follows:

$\begin{array}{lll}\mathrm{T}_{1} \mathrm{H}_{1} & \mathrm{~T}_{2} \mathrm{H}_{1} & \mathrm{~T}_{3} \mathrm{M}_{1} \\ \mathrm{~T}_{1} \mathrm{M}_{2} & \mathrm{~T}_{2} \mathrm{H}_{2} & \mathrm{~T}_{3} \mathrm{M}_{2} \\ \mathrm{~T}_{1} \mathrm{M}_{3} & \mathrm{~T}_{2} \mathrm{H}_{3} & \mathrm{~T}_{3} \mathrm{~N}_{3}\end{array}$

The position of these whole plots was at random within each replication, whether in the greenhouse or in the rield. The whole plots were also randomized in the controlled temperature chambers. 

Each of the whole plots consisted of 12 sub-plots (rows) made up of all conbinations of the 3 exposure periods and the 4 varieties, as Iollows:

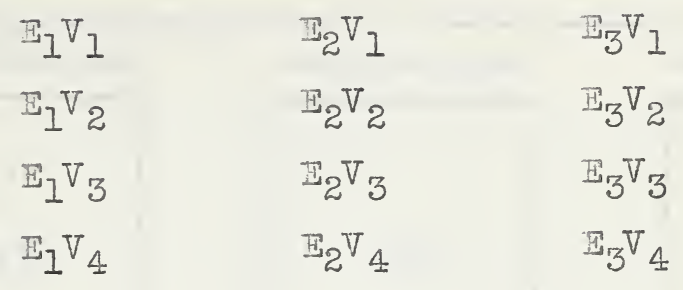

The position of the sub-plots within each whole plot was at random, with a ditterent randomization in each case. Lach sub-plot (row) consisted of 25 seeds. In order to I'acjlitate setting out, the sub-plots were transferred to the Iield in the same rotation as they appeared in the llats. The sub-plots, in the fielo, becare single 25 loot rows spaced. 3 Ieet apart, and with the seeds placed at intervals of approxinately 1 toot.

The arrangenent of the whole plots within one replication in the field is shown diagramatically in Figure 2 , while the arrangement of the subplots within a single whole plot is illustrated in Pigure 3 .

\section{Methods of Collecting Data}

According to Heyer and Anderson (15), germination is completed with the rupture of the seed coat and the energence ot the young plant. For the purpose of this study, gemination was considered to be complete when one prominent seeding lear had energed fron the coleoptile, above the surtace of the medium. 



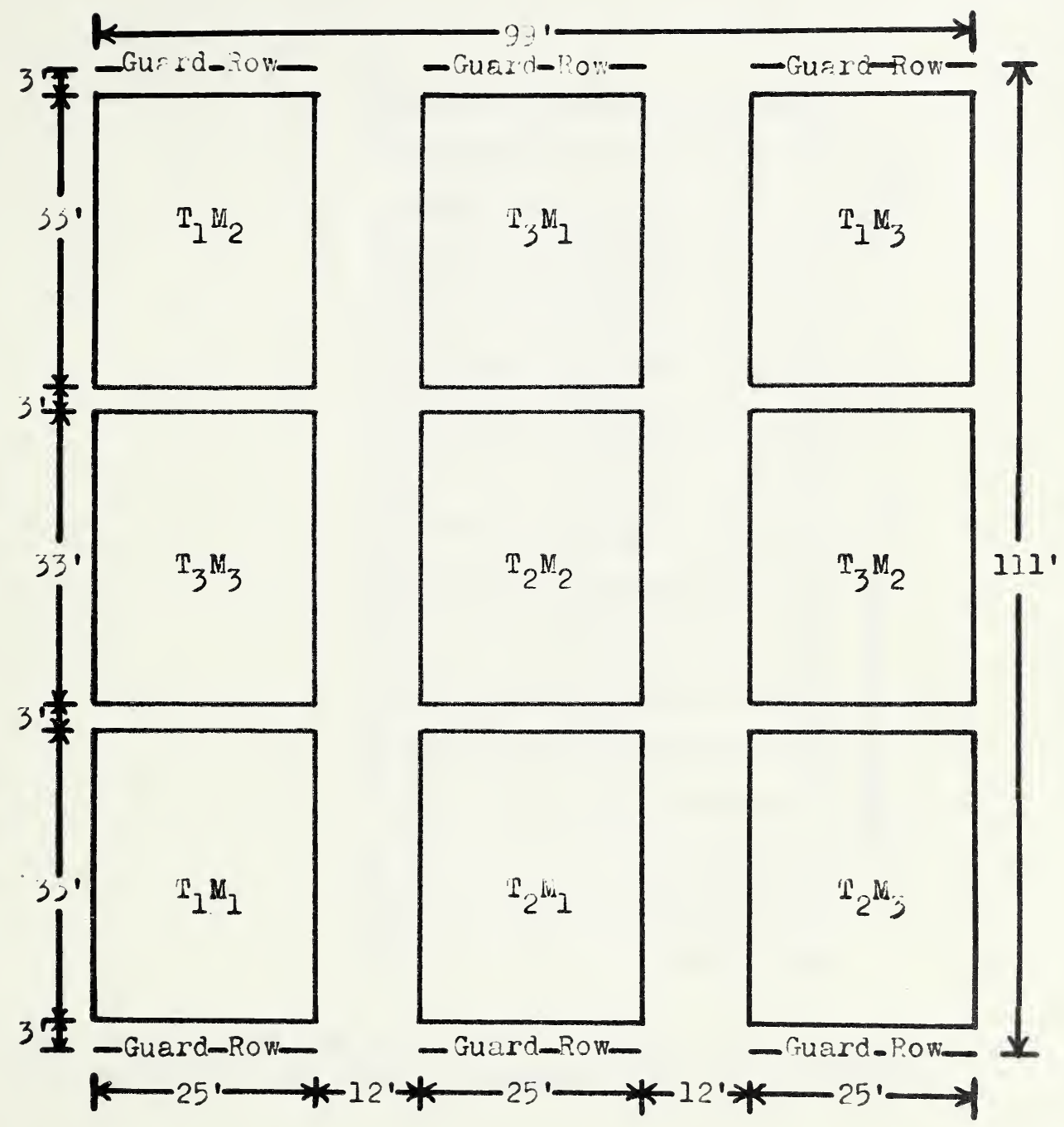

Fig. 2. Ilan of one rejliction shoring the arrengement of the whole piots. 



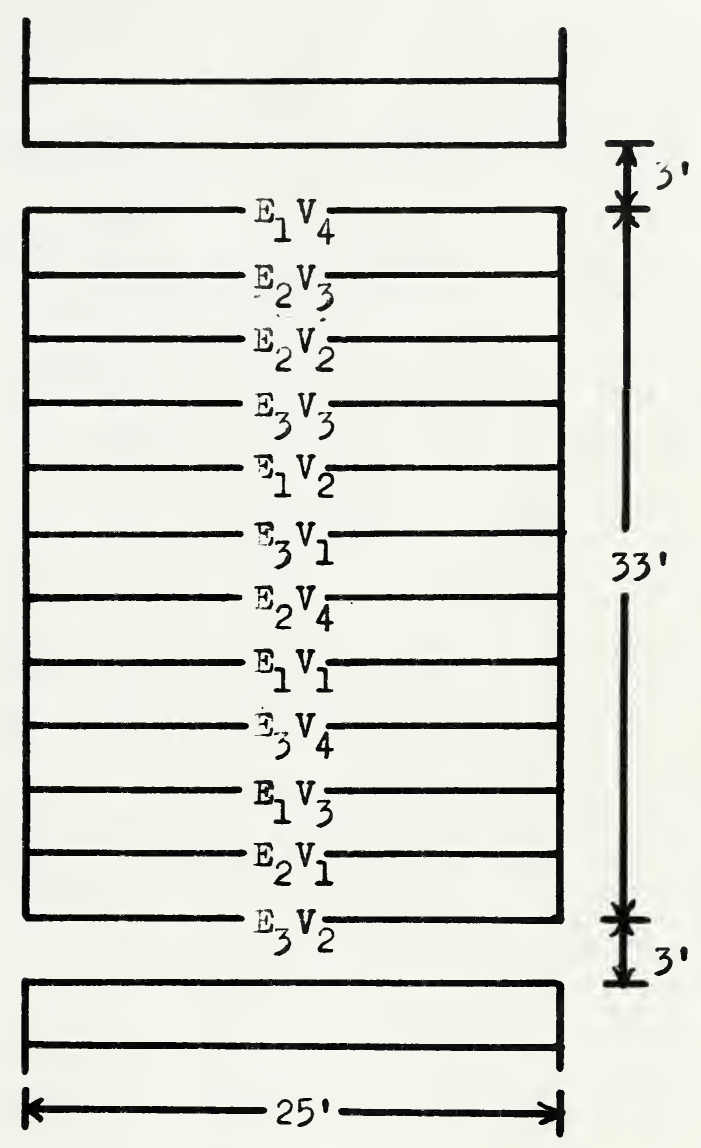

- Fig. 3. Plan of one whole plot showing the arrangement of the subplots (the same arrangement as in the flats). 


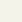


In the greenhouse trials, counts ot' all the emerged seedings were made when it had been ascertained that no Iurther germination would take place. The vigor oI the seedlings was also recorded.

For the field trials, seealing counts were made before the material was transferred to the t'ield and again when it was certain that no more seeds would gerninate. It nay be noted here that the germination oI seed exposed at $15^{\circ} \mathrm{C}$. was almost complete when the transter to the field was made. It was, therefore, necessary to transplant all the erierged seedlings. As a result, considerable losses were incurred and tinal stands were orten lower than the initial gemination. The Iinal stands and the initial gernination were compared and the higher figure ol the two was taken to be the r'inal germination.

Data were also collected regarding the maturity of the numerous sub-plots. These data vere based upon the dates on which 50 per cent or the plants had completed silking.

No yỉeld data were collected because or rrost damage to the entire plot area belore the varieties had matured surificiently

\section{Methods of Analysing the Data}

The data were analysed to determine the elfects of the diflerent iactors by means of the analysis of variance. The significance of all main eftects was determined and Least Significant Difierences were calculated where the F values obtained vere signiticant. 

Separate analyses were computed I'or tine separate trials. The results ol the trials could not be combined because of certain dissimilarities, nanely, the greenhouse trials

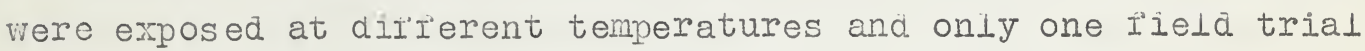
was successiully carried out, due to weather conditions that are discussed later.

All data vere recorded as percentages and it was necessary to transiom them using the angular transiornation (percentage $=\sin ^{2} \theta$ ) as laid out by Hayes and Immer (IU). The relationship or angles (in degrees) to percentages is iLustrated in Appendix $V$.

\section{Climatic Influences}

In 1950, the transier to the Iielo was made into relatively dry soil under warm weather conditions. The entire plot area was sprinkled with appoximately one inch oI water immediately alter the transier to the Iield had been completed, giving excellent conditions Ior the completion oI germination.

In 1951, on the other hand, the transier was made under decidediy aaverse soil and weather concitions. The soil was very wet and Iow temperatures persisted Ior an extended period. On the Iourth day arter the transier was made (June 26) a heavy snoviall occurred. The plots were lett Ior approximately one month and aiter close observation it vas considered that the cold and snow had nullilied the eliect ot the previous tempelature treatments, as no treatment dirlerences were apparent. Is a result or this careiul inspection, it was decided to abancion the trial. 

Greenhouse temperatures were relatively low auring the time that the seeds vere undergoing completion oI germination. As a result, gernination was rather slow. The temperatures could not be altered because oI the presence ol other plants wich would not tolerate the higher temperatures.

\section{RESULTS}

The results oI this project IaIl Logically into 3 separate phases, namely the Field Mrial 1950, Greenhouse Trial I95U-5I, and the Greenhouse Prial Fall 1951. Each of these phases mill be discussed individually。

\section{Pield Trial 1950}

General views of the plot area are shown in Figures 4, 5, and 6.

Under near ideal soil and weather conditions, germination progressed rapicily aiter the seed had been transIerred to the rield. On the other hand, plants which had been transplanted showed very little progress lor about 10 days, arter which time growth was quite rapid. Plants, Irom the lower temperature treatments, were generally shorter than those from the $15^{\circ} \mathrm{C}$. treatnent. There was no consistent dirierence in the number or tillers per plant and the smaller plants appeared to be as healthy as the larger plants.

At silking time no consistent differences in maturity could be detected between treatments within varieties. There were 



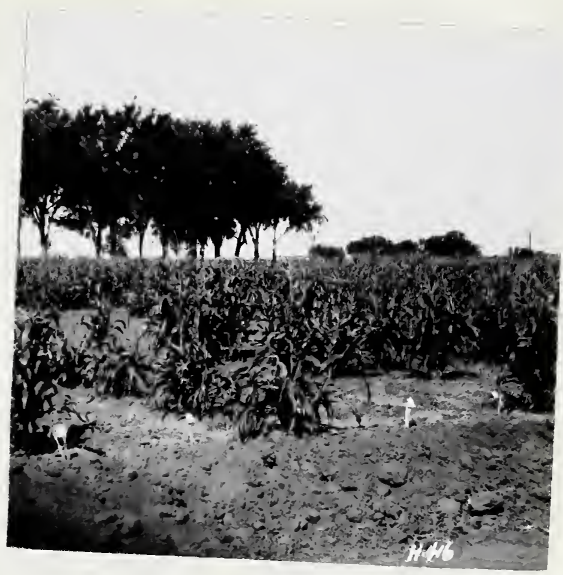

Ii̊g. 4 .
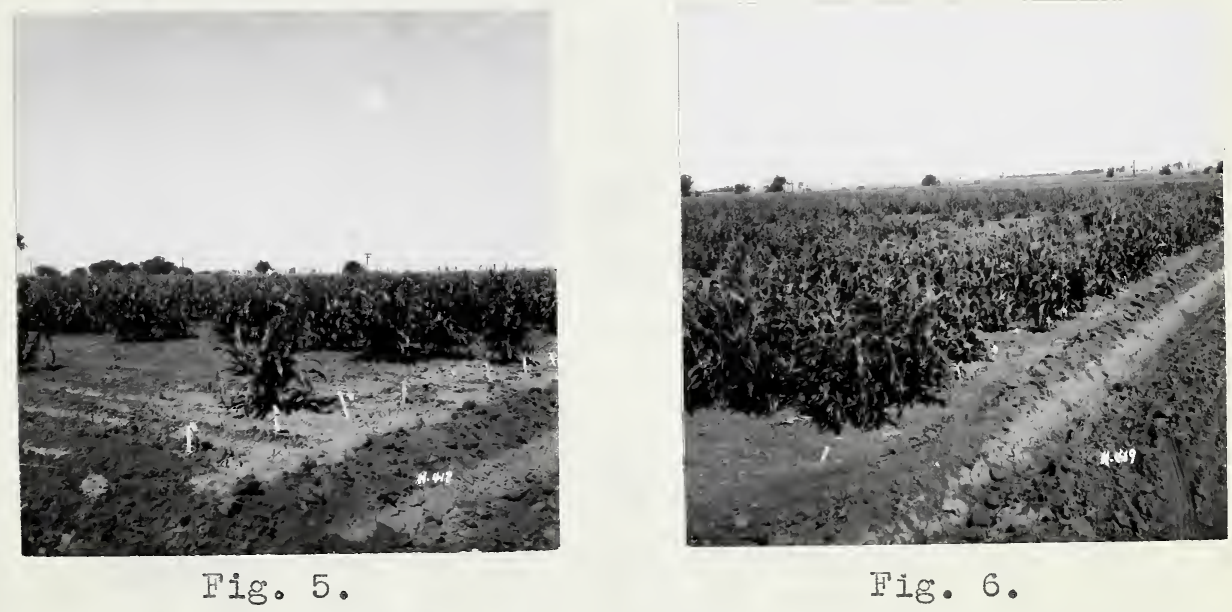

Pigures 4-6. General views of the plot area. Pield Trial 1950. Note that extensive gaps appear in certain plots - these represent treatments where germination was seriously inhibited 



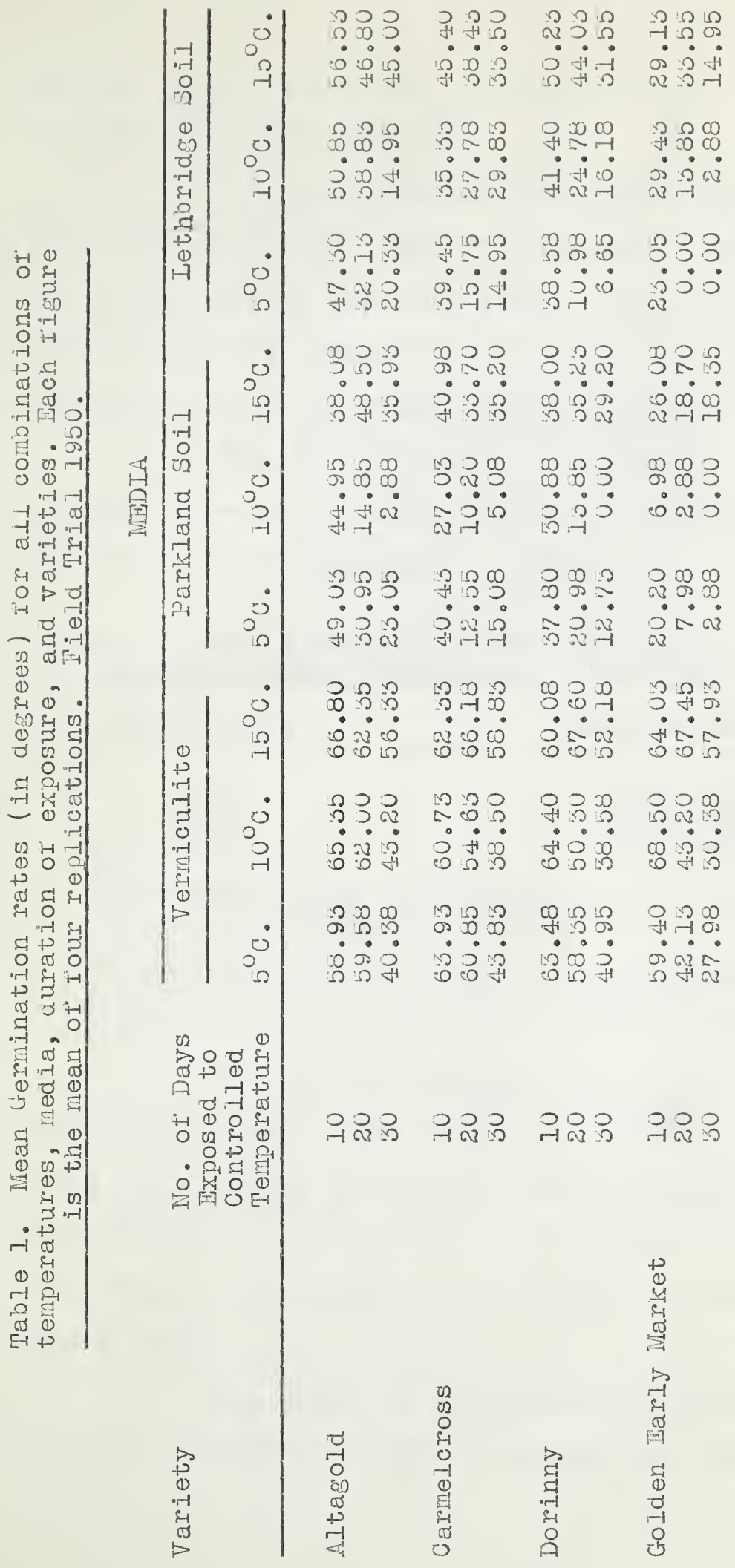


however, normal variations between early and midseason varieties. No yield data were realized.

Table 1 lists the mean germination rates ror all treatments (converted Irom percentages to degrees). Tach Iigure is the mean of 4 replications. An analysis or variance (Appendix I) was computed for the complete data, and certain treatment effects were observed to be significant.

The rate oI germination of sweet corn was significantly affected by the termeratures to which the seed had been exposed, as illustrated in Table 2 .

Table 2. Mean germination rates (in degrees) for each of the temperature treatments. Field Trial 1950.

Temperature $50^{\circ} \mathrm{C}$.
$10^{\circ} \mathrm{C}$.
$15^{\circ} \mathrm{C}$.
Germination Rate

31.74 degrees

30.70 degrees

44.69 degrees

Ieast Signiticant Difference $= \pm 9.77$ degrees F value $=9.79$

\#xceeds the 5 per cent level of significance

The mean germination rate at $5^{\circ} \mathrm{C}$, and $10^{\circ} \mathrm{C}$. were both signilicantIy lower than that at $150 \mathrm{C}$, but there was no basis for assuming any real difference between the eftects of the two lover temperatures. The influence of temperature on the stands of the plants in the rield is illustrated in Figures 7 to 15 .

The nature of the germinating medium also significantly atrected the rate of germination (Table 3). Germination 



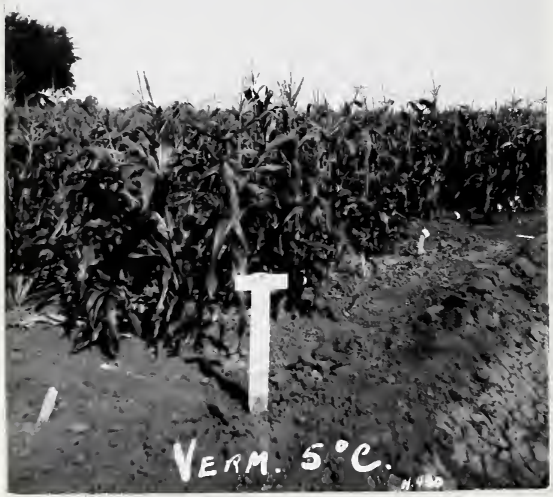

Fig. 7

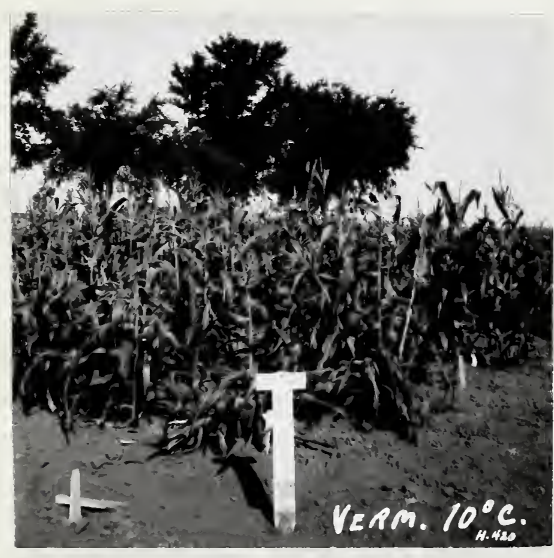

Fig. 8

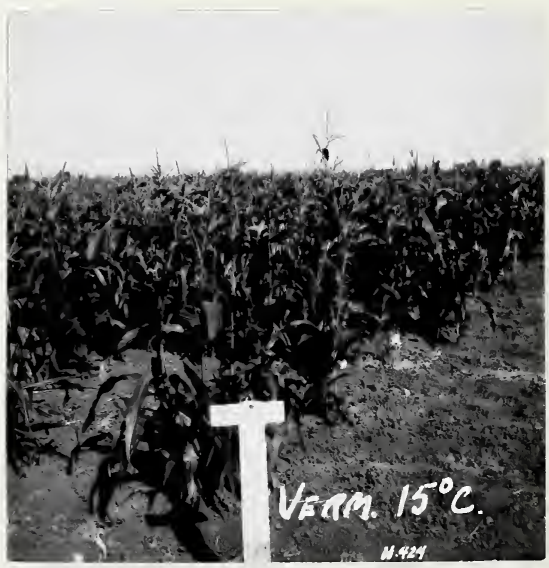

Fig. 9

Figures 7 - 9. The efrect of temperature upon the stands or sweet corn sown in vermiculite. Field Trial 1950. 


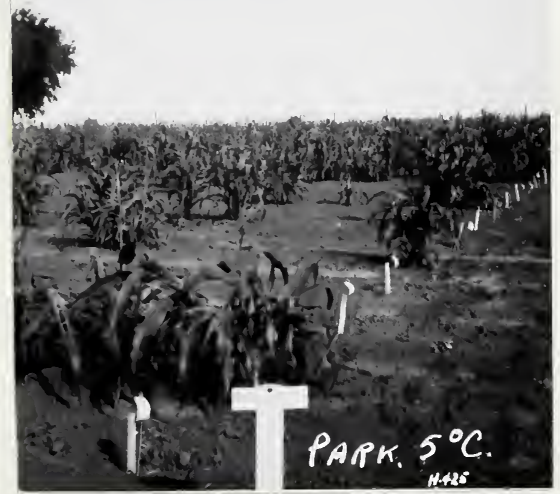

Fig. 10

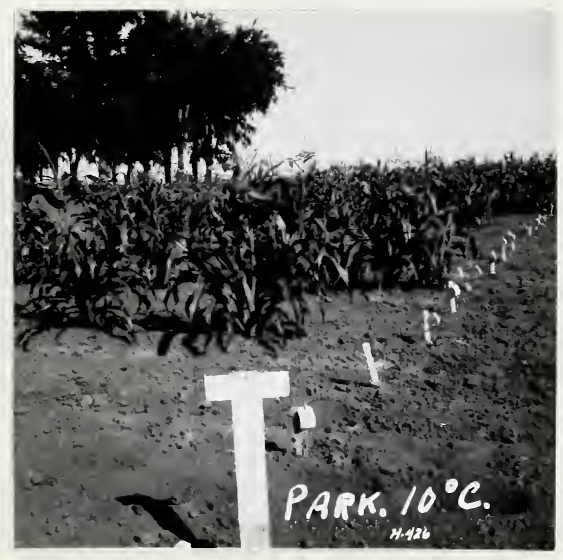

Fig. 11

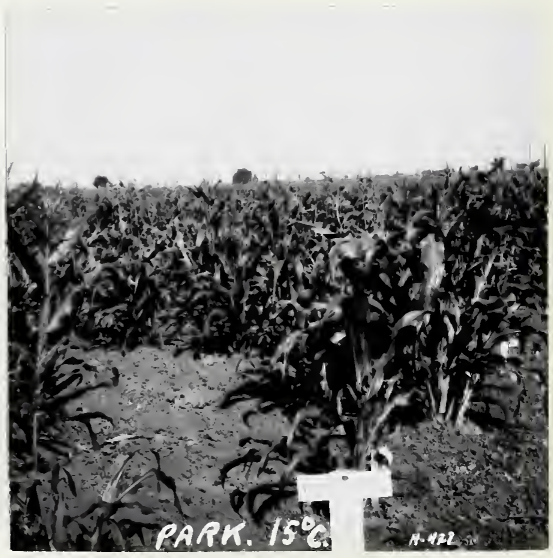

Fig. 12

Figures 10 - 12. The efrect of temperature upon the stands of sweet corn sown in Parkland Soil. Field Prial 1950. 



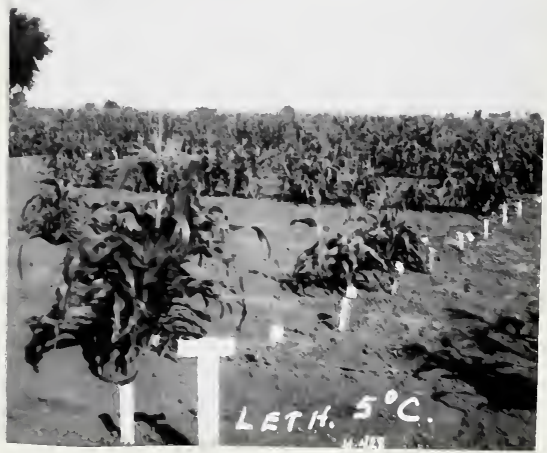

Fig. 13

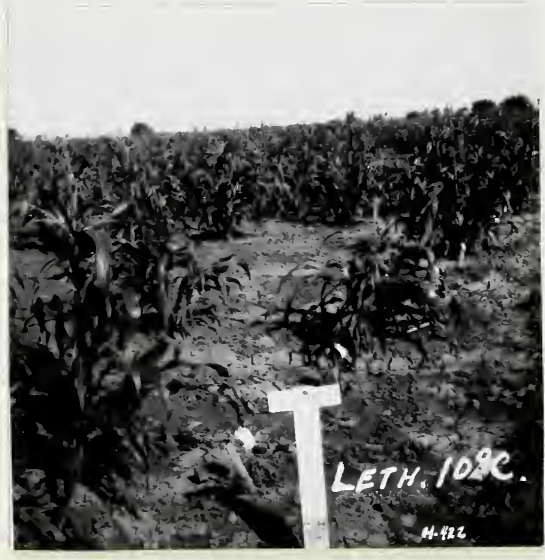

Fig. 14

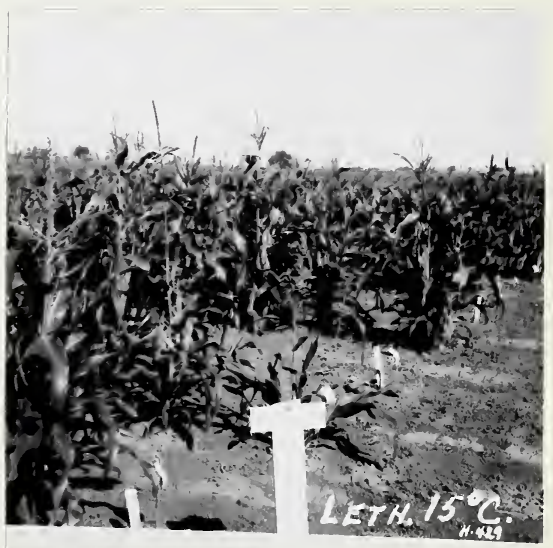

Pì․ 15

Tigures 15 - 15. The ertect or temperature upon the stands of sweet corn sown in Lethbridge Soil. Field Trial 1950. 


\section{.}


in both Parkland and Lethbridge soils was signilicantly lower than in Vemiculite. There was no indication or any real dilI'erence between the eflects of the two soil types upon gemination.

Table 3. Mean germination rates (in degrees) for each media. Field Trial 1950

Iifedium Germination Rate

Vermiculite

Parkland Soil

Lethbridge Soil

55.05 degrees

25.10 degrees

29.00 degrees

Least Signiricant Ditrerence $= \pm 9.77$ degrees $F$ value $=46.57$ tet

Exceeds the 1 per cent Ievel or significance

The significance of the Iirst order interaction between temperatures and media indicates a differential efrect of temperature from one nedium to another. The combined efiect of the two factors is shown graphically in Figure 16, photographically in Figures 7 to 15, while Table 4 lists the means of the combined treatments.

Table 4. Mean germination rates (in degrees) for all. combinations of temperatures and media. Field Trial 1950

lifedium

Temperature

\begin{tabular}{llll} 
& $50^{\circ} \mathrm{C}$. & 1000. & $150 \mathrm{C}$. \\
\hline Verniculite & 51.63 & 51.63 & 61.83 \\
Parkland Soil & 22.81 & 13.28 & 35.14 \\
Lethbridge Soil & 20.80 & 27.20 & 39.09 \\
& F value $=2.85$ & &
\end{tabular}

\# Mxceeds the 5 per cent level of significance 
It may be observed in Table 4 and Figure 16 that the germination rate dropped to a greater extent from $15^{\circ} \mathrm{C}$. to IU $\mathrm{O}^{\circ}$., and $5^{\circ} \mathrm{C}$. In soil than it did in Vermiculite. It is interesting to note, at this point that the germination in Parkland Soil was lower at $10^{\circ} \mathrm{C}$. than at $5^{\circ} \mathrm{C}$.

Gemination was signilicantly aliected by the duration or exposure, as illustrated in Table 5 . The ju-day exposure produced a significantly lower germjnation rate than the I0-day exposure. The germination rate lor the 2U-day exposure period was intermediate between the longer and shorter exposures but did not dirter signiticantly from either。

Table 5. Nean germination rates (in degrees) Ior the different durations or exposure. Field Trial 1950

Number of

Days Exposed
Germination Rate
10

20

30
45.68 degrees

35.39 degirees

26.11 degrees

Least Significant Dirierence $=\frac{1}{2} I I .53$ degrees P value $=11.55$

E Exceeds the 5 per cent Ievel or signilicance

Table 6. Mean gemination rates (in degrees) ror alI combinations, duration oI exposure and temperature. Field Mrial lyb

Number of

Dajs Ixposed

Temperature

$\begin{array}{llll}10 & 45.05 & 40.8 \% & 48.16 \\ 20 & 29.05 & 29.76 & 46.88 \\ 30 & 20.74 & 18.51 & 39.09\end{array}$

F value $=11.69$

Exceeds the I per cent level oI significance 



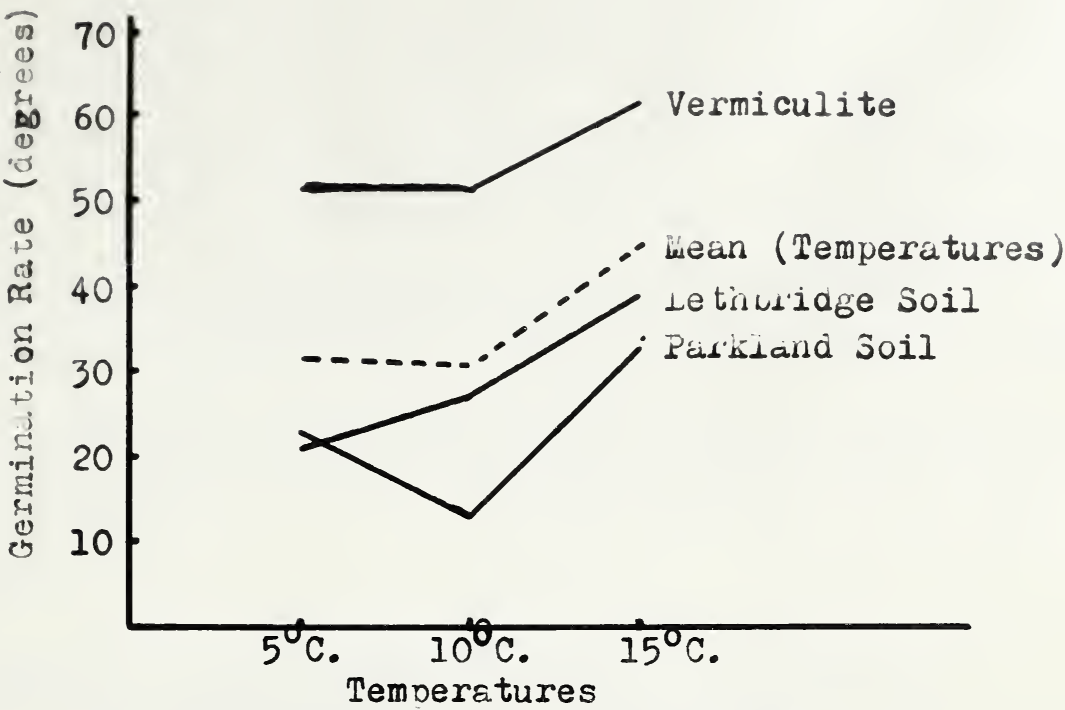

Fig. 16. The combined effect of temperatures and media upon the germination rate of sweet corn. Field Trial 1950.

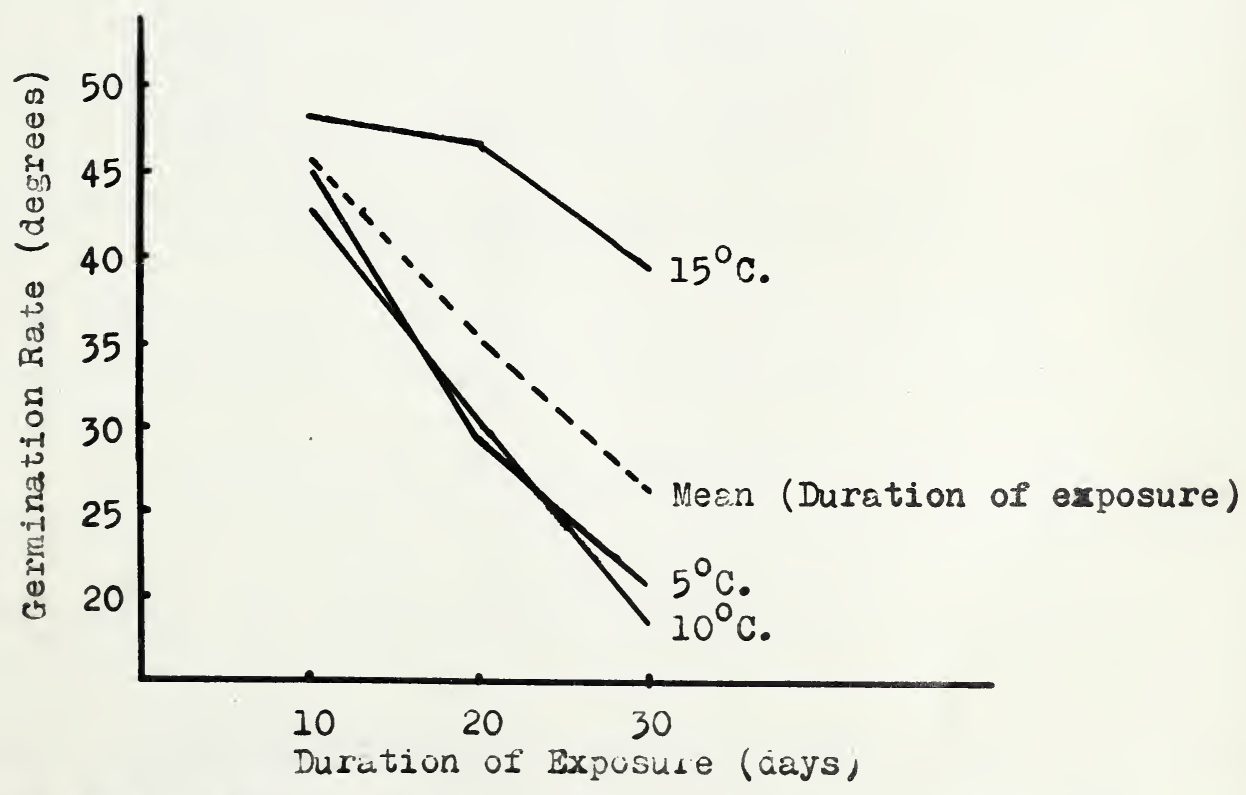

Fig. 17. The combined effect of the duration of exposure and temperature upon the germination rate of sweet corn. Field Trial 1950. 

The signiticance of the interaction between the duration of exposure and temperature indicates that the eliect of temperature was diteerentially artected by the duration of exposure. The mean germination rates are tabulated in Table 6 , and the elrect is illustrated graphically in Figure I7. The graph shows how germination at $15^{\circ} \mathrm{C}$. was only slightly reduced as the duration of exposure increased, whereas germination at the two lower temperatures was reduced sharply under similar conditions.

Table 7. Wiean gernination rates (in degrees) for varieties. Field Trial 1950.

\begin{tabular}{ll} 
Variety & $\begin{array}{c}\text { Germination } \\
\text { Rate }\end{array}$ \\
\hline Altagolo & 42.77 degrees \\
Carmelcross & 37.42 degrees \\
Dorinny & 56.26 degrees \\
Golden Marly Market & 26.37 degrees
\end{tabular}

Least signilicant Difterence $= \pm 7.49$ degrees F value $=10.07$ trit

- Exceeds the 1 per cent level of signiricance

The differences in the gemination rates of the varieties could be observed visually in the field. Ihe analysis oI variance bore this out as illustrated in Table \% Golden Early farlet germinated at a significantly lower rate than the other three varieties. Altagold geminated signiricantly better than Golden Early harket but no actual difference vas detected between Altagold, Carmelcross, and Dorinny. 
$\Lambda$ differential effect of nedia upon the germination of the varieties is indicated in the signilicance or the interaction between varieties and nedia. The relationship is illustrated graphically in Figure 18, and the mean germination rates are listed in Table 8. IS may be observed in Figure 18, all varieties geminated very well in Vermiculite, while in the two soils germination is reduced in varying degrees according to variety.

Mable 8. Hean germination rates (in degrees) or varieties as aliected by the geminating medium. Field Trial 1950

\begin{tabular}{llll} 
Variety & Vermiculite & $\begin{array}{c}\text { Parkland } \\
\text { Soil }\end{array}$ & $\begin{array}{c}\text { Lethbridg } \\
\text { Soil }\end{array}$ \\
\hline Altagold & 57.21 & 32.02 & 39.22 \\
Carmelcross & 56.64 & 24.47 & 31.16 \\
Dorinny & 55.10 & 24.27 & 29.37 \\
Golden Early Market & 51.22 & 11.56 & 16.32
\end{tabular}

$$
\text { F value }=4.81 \text { t }
$$

Wxceeds the 1 per cent level of significance

Table 9. Wean germination rates of sweet com in ditterent media for varying durations of exposure. Field rrial 1950

Mediun Duration of Exposure (days)

\begin{tabular}{llll} 
& 10 & 20 & 30 \\
\hline Verrniculite & 63.16 & 57.88 & 44.08 \\
Parkland Soil & 33.39 & 20.86 & 15.03 \\
Lethbridge Soil & 40.56 & 27.24 & 19.22
\end{tabular}

$$
\text { Palue }=2.93
$$

सxceeds the 5 per cent level of signiricance 



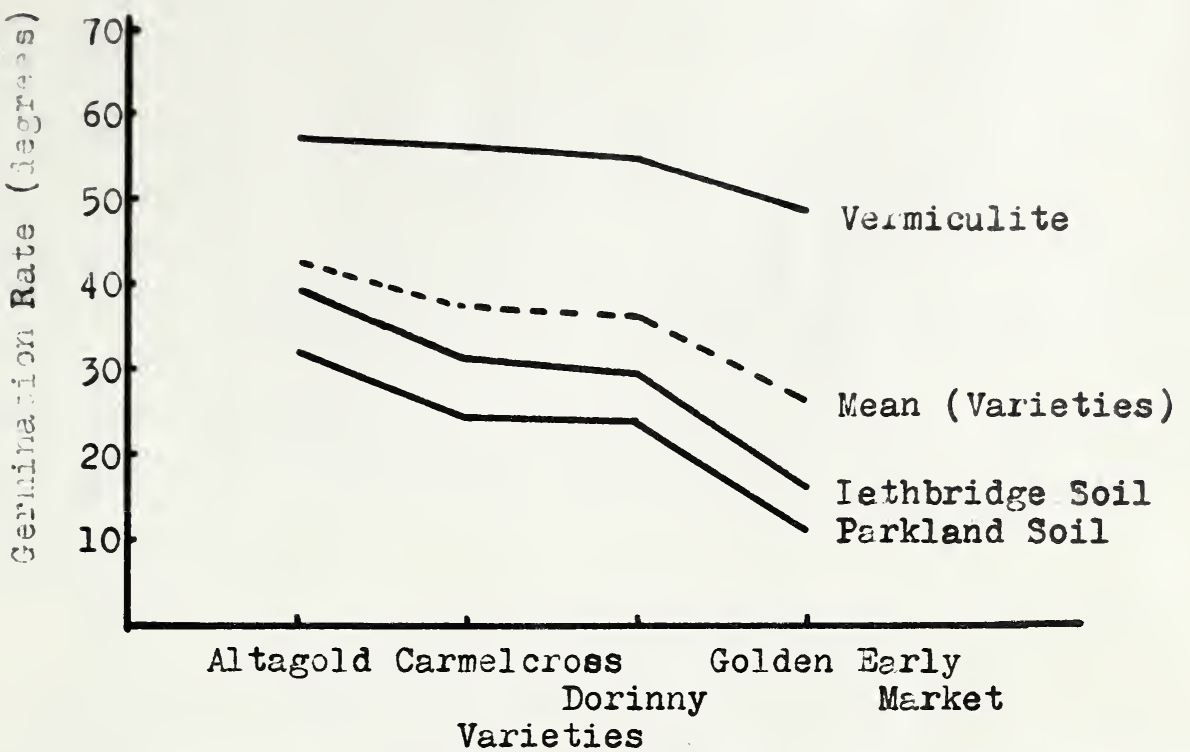

Figure 18. The effect of medium upon the rate of germination of four valieties of sweet corn. Field Trial 1950.

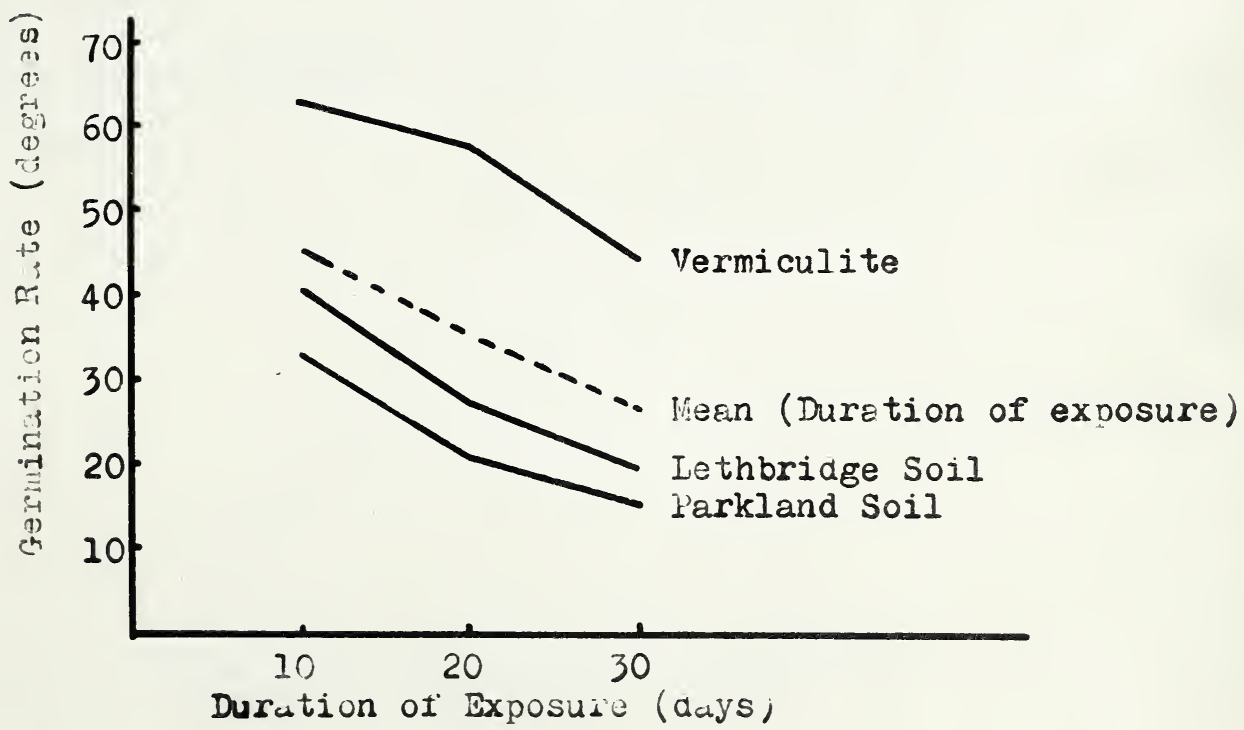

Figure 19. The combined ef ect of medium and durition of exnosure uoon the germination of sweet corn. Field Trial 1950. 

The interaction between durations of exposure and media was signiticant to the tive per cent level indicating that the eifect oI media was altered somewhat by the duration of exposure. Figure 19 shows that the germination rate in Vermiculite $\mathrm{I}$ ell nore slowly than in soils as the duration of exposure was increased to 20 days. However, when the duration of exposure was increased, still Iurther, to 30 days the germination rate in Vermiculite fell more rapidly. The mean rates are presented in Table 9 .

The interaction between varieties and terneratures was not significant indicating that the varieties were not dirferentialiy afrected by temperature. This is mell illustrated in Figure 20 where it can be seen that the curves ror varieties are nearly parallel to one another. There was, thererore, no difference in the response of the varieties to the aifierent temperatures. 



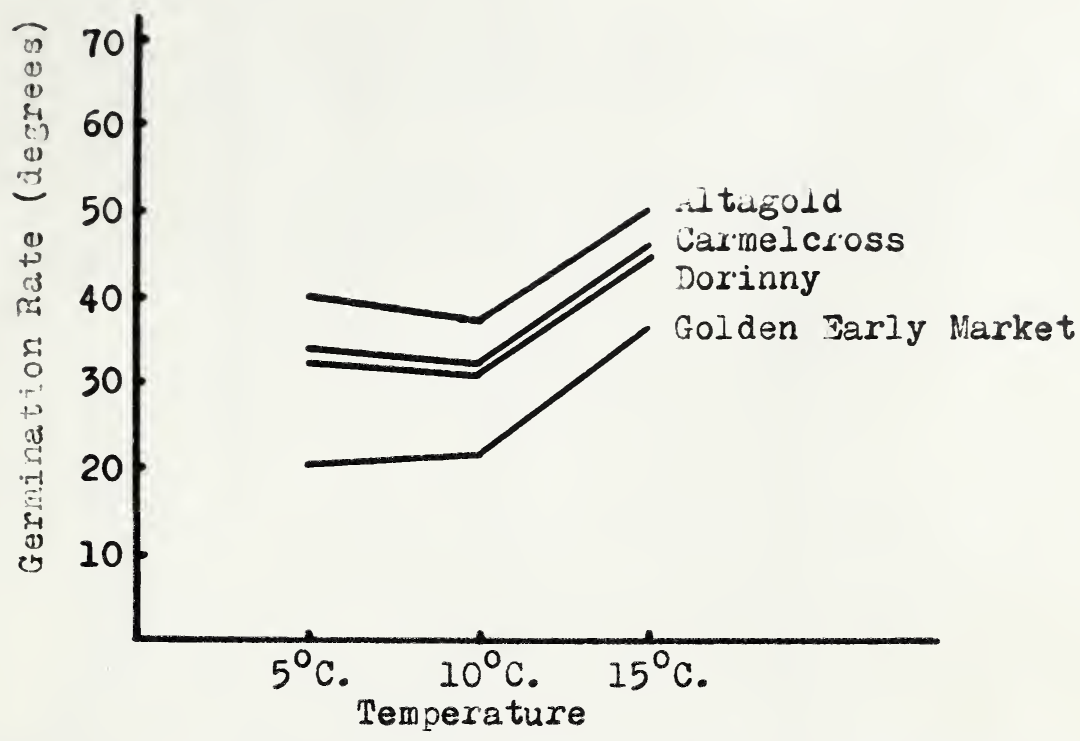

Fig. 20. The efiect of temperature upon the germination of four varieties of sweet curn. Field Trial 1950.

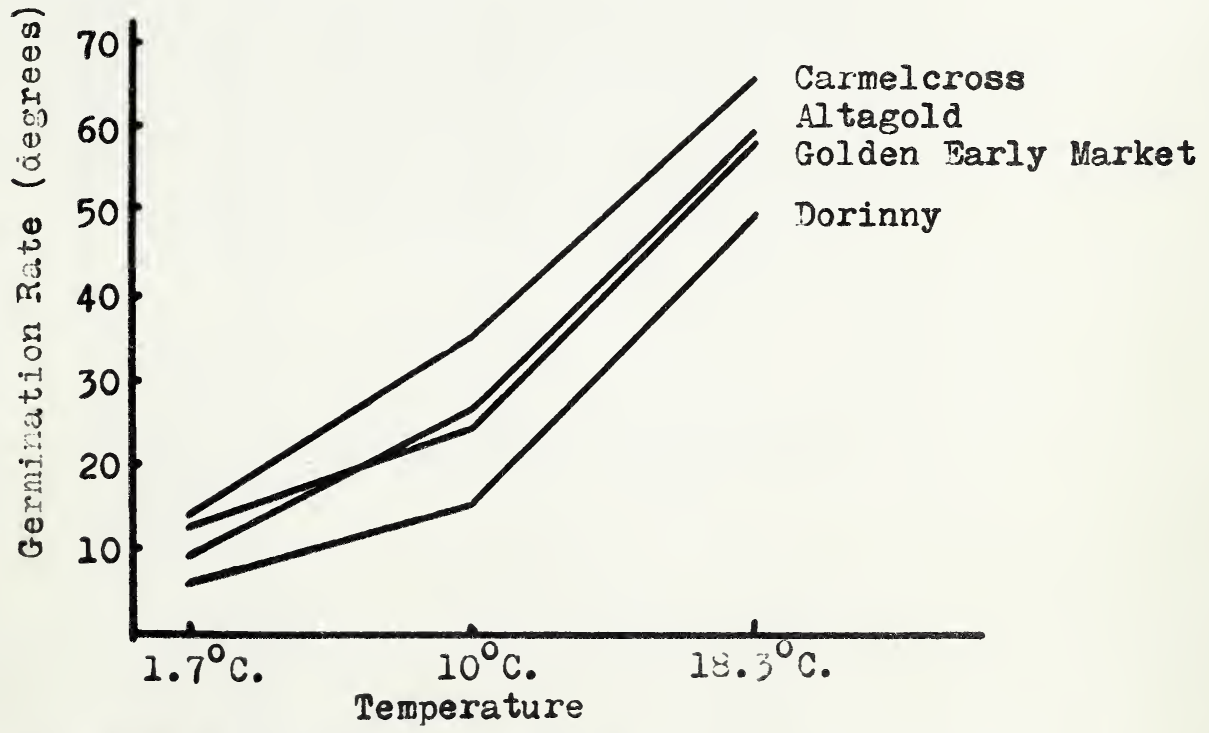

Fig. 21. The efiect of temoerature upon the germination of four varieties of sweet corn. Greenhouse Irial 1950-51. 



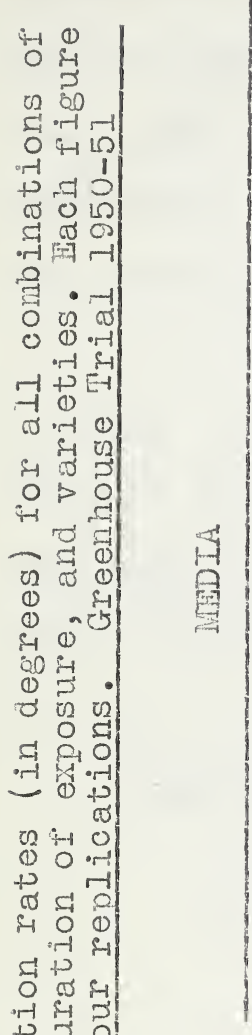

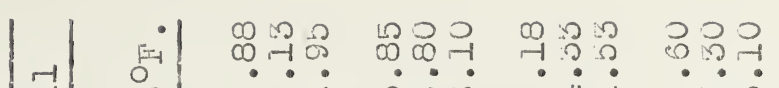

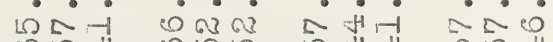
约

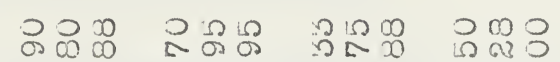

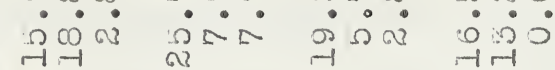

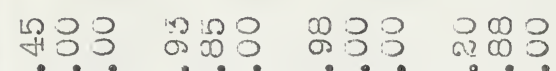
एंல்

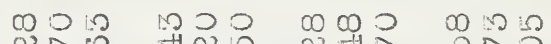
U.?

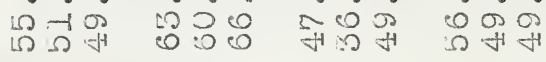

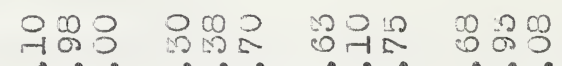

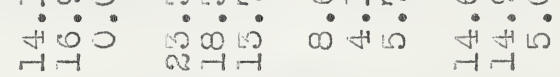

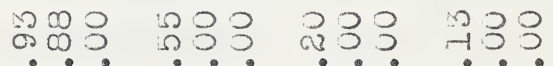
嗢

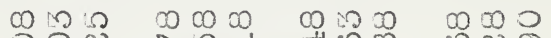

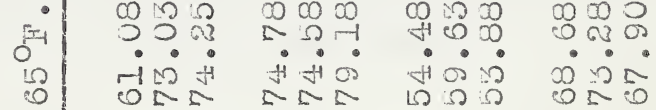
+)

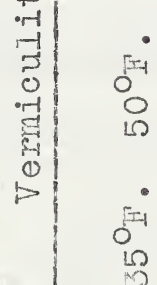

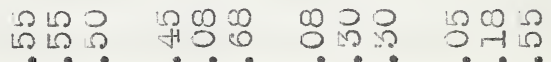

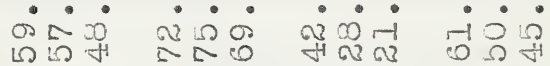

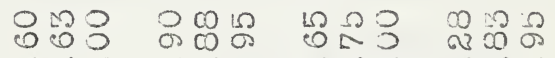

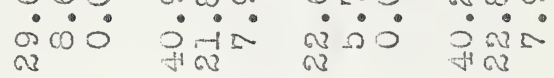

क 20

.

혀 สิ (1) r.

$80 \stackrel{0}{0} 0$

ฮี

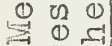

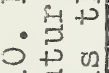

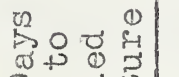

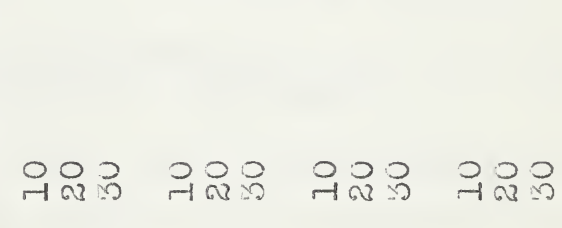
a-1 8 ठ 0 调 \& 0

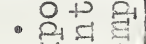

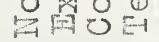

E1 



\section{Greenhouse Trial 1950-5I}

IS previously noted, this trial was conducted at temperatures of $1.7^{\circ} \mathrm{C}, 10^{\circ} \mathrm{C}$, and $18.3^{\circ} \mathrm{C}$. rhe analysis of Variance vas computed in the sane manner as Ior the 1950 Field Mrial, and is shown in Appendix II. Table lu lists the mean germination rates Ior all treatments, each rigure being the mean of the Iour replications.

Temperatures vere again tounc to cause highly significant diferences in the germination rates of sweet com. rabie 11 shows that the gemination rates for $1.7^{\circ} \mathrm{C}$. and $10^{\circ} \mathrm{C}$. were signiIicantly Iower than that for $18.3^{\circ} \mathrm{C}$, but did not diIter signiIicantiy from one another.

Table 11. Wean gemination rates (in degrees) for teriperatures. Greenhouse Trial I950-51

$\frac{\text { Temperature }}{\text { Germination Rat }}$

Least Significant Difterence $= \pm 22.63$ degrees $\mathrm{F}$ value $=18.70 \mathrm{H}$

Exceeds the 1 per cent Ievel or signilicance

Differences in germination rates between the ditierent media did not prove to be signilicant in this trial. ( 5 . 50 ).

The signiticance or the interaction between temperature and media incicated that nedia altered the eitects or temperature in a diterential manner, as shown in Table lz and in Figure 2z. 


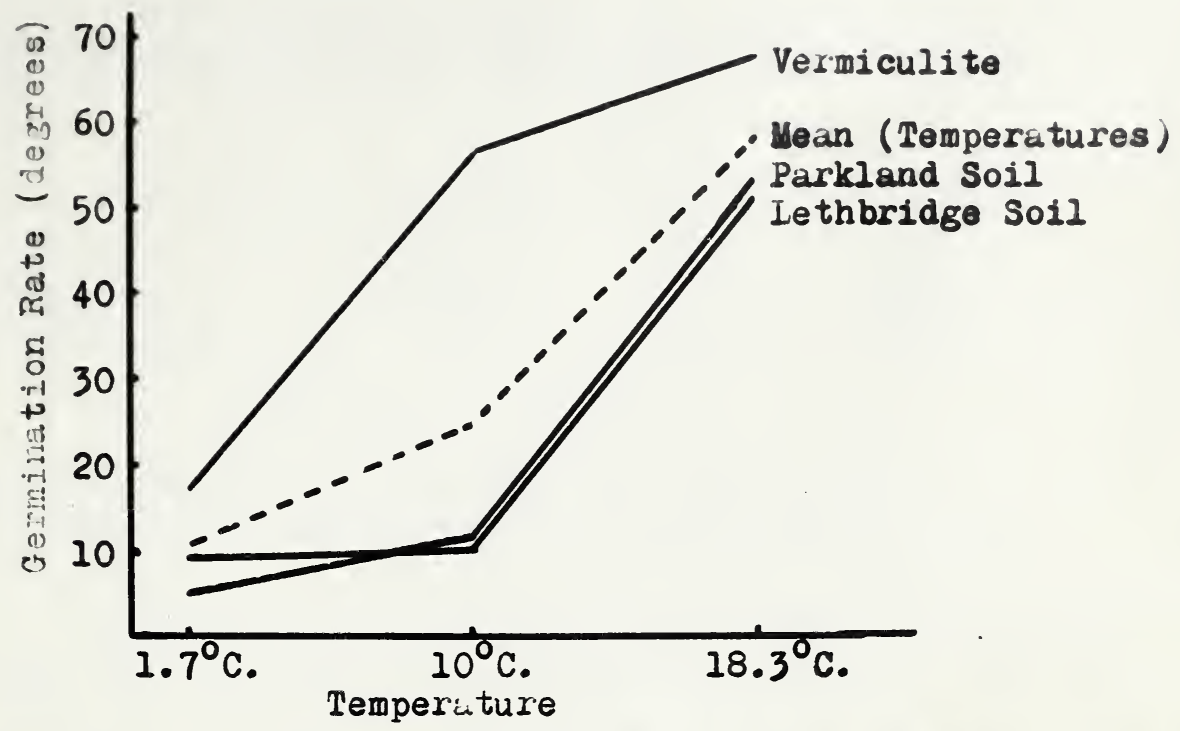

Fig. 22. The combined effect of temperatureseand media upon the germination rate of sweet corn. Greenhouse Trial 1950-51.

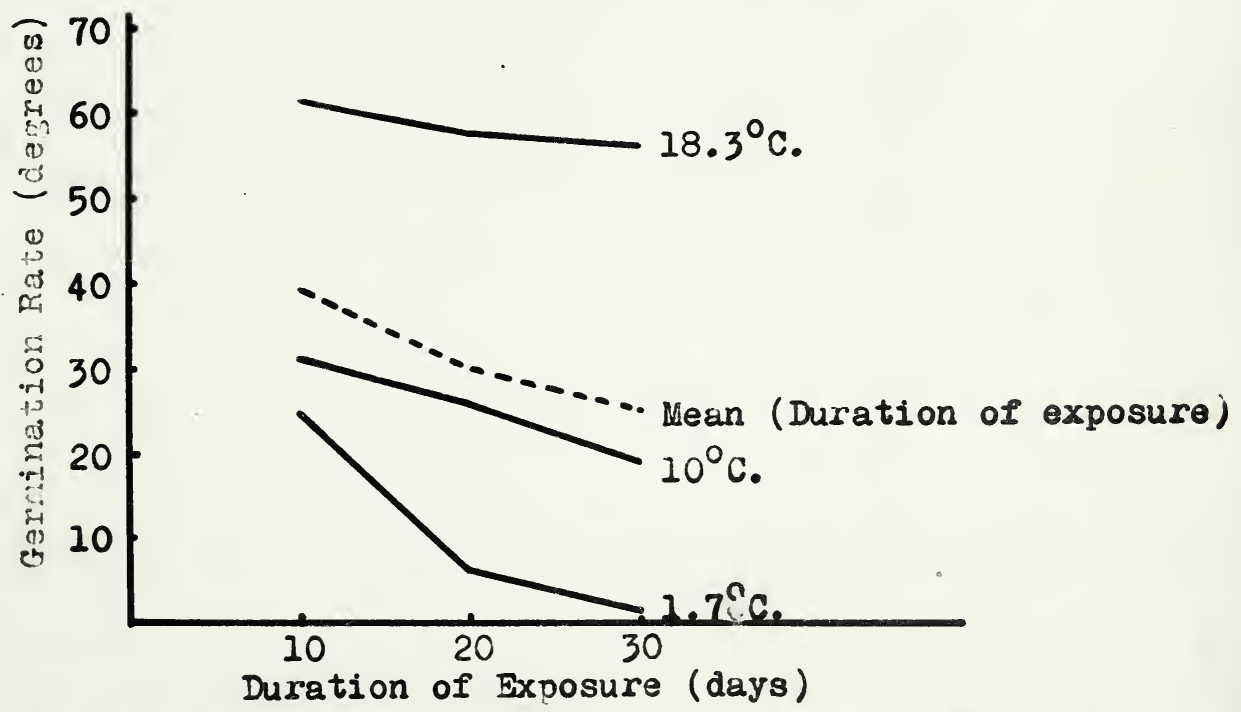

Fig. 23. The combined effect of duration of exposure and temperature upon the germination rate of sweet corn. Greenhouse Trial 1950-51. 

Table 12. Mean germination rates (in aegrees) tor temperatures and media. Greenhouse Trial Iybu-bI

Hediun

\begin{tabular}{|c|c|c|c|}
\hline & $1.7^{\circ} \mathrm{C}$. & $10^{\circ} \mathrm{C}$ & $18.3^{\circ} \mathrm{C}$ \\
\hline Vermiculite & 17.57 & 56.20 & $6 \% .89$ \\
\hline $\begin{array}{l}\text { Parkiand Soil } \\
\text { Lethbridse Soil }\end{array}$ & 3.69 & 11.63 & 53.40 \\
\hline Lethbriage Soil & 9.27 & & 52.96 \\
\hline
\end{tabular}

Temperature

यEx Ixceeds the 1 per cent level or signiricance

Figure 22 illustrates that germination at 1.700. and $18.3^{\circ} \mathrm{C}$. are proportional in their relationship, but that at $10^{\circ} \mathrm{C}$. germination was much higher in Vemiculite than in the two soils.

The duration of exposure, in itseli, did not signiIicantly ariect gemination although there was a direrential erlect ol the duration or exposure upon activity or temperatures, as incicated by the signiticance of the interaction between duration of exposure and temperature. As shom in Pigure 2:5, the duration of exposure did not greatiy aliect the germination rates at $18.30 \mathrm{C}$, and oniy s Ijghtly decreased the rates at I000. However, at $1.7^{\circ} \mathrm{C}$. the germination rate was reuced sharply as the duration or exposure was increased. Iiean germination rates Ior the conbined Iactors are listed in Table 15. 


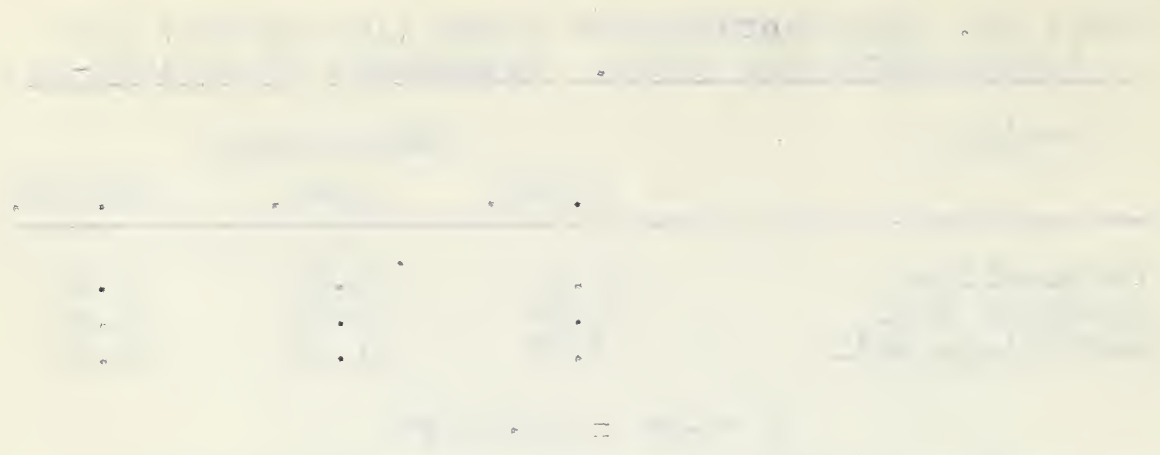


rable 15. liean germination rates (in degrees) por all combinations, duration of exposure and temperature Greenhouse Mrial 1950-51

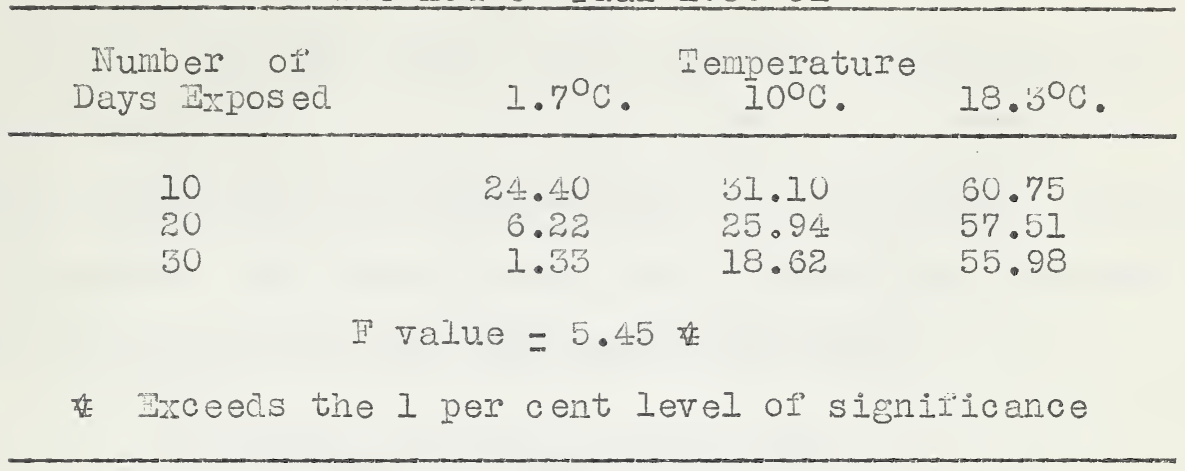

Significant difterences were found between the geminating ability of the varieties included in the trial as shown in Mabie 14 .

Table 14. Nean germjnation rates (in degrees) for varieties. Greenhouse Trial 1950-5I

Variety

Germination Rate

Altagolã.

Carmelcross

Dorinny

Golden Early Narket
31.47 degrees

38.21 degrees

23.56 degrees

32.06 degrees

Least Signiticant Difterence $= \pm 4.49$ degrees F value $=17.09$

Exceeds the 1 per cent level of significance

Applying the least signiticant dirference to Table I4 it is observed that Camelcross geminated signiricanty better than the other three varieties, and that Dorinny had a significantly Iover rate of gemination than all other varieties. 

There was no real diference between the germinatjng ability ot Altagolà and Golden Early Ifarket.

$$
\text { In this trial, as in the } 1950 \text { rield trial, no }
$$

significance $(\mathrm{F}=1.11)$ was obtained for the interaction between varieties and temperatures. It is clearly iliustrated in Figure $2 I$ that the efrects of the temperature treatments upon the difierent varieties vere almost identical.

\section{Greenhouse Trial - FaII I95I}

This greenhouse trial was conducted under identical temperature conditions to the 1950 Iield trial, except that gemination was completed in a greenhouse. The nean germination rates Ior all treatnent combinations are listed in Table 15, and the completed analysis or variance is tabulated in Appendix III.

The elfects of the various treatments are illustrated photographicaliy in igures 28 - 34. The plants rrom the $15^{\circ} \mathrm{C}$. treatment were severely etiolated and were not photographed.

As in the two previous trials, temperatures were responsible tor highly signiticant ditterences in the gemination rates or sweet corn. In Pable 16 it may be observed that both the $5^{\circ} \mathrm{C}$. and $10^{\circ} \mathrm{C}$. temperatures produced signilicantly lower germination rates than aid the $15^{\circ} \mathrm{C}$. temperature, while no real difference could be detected between the elfects of the two lower temperatures. 



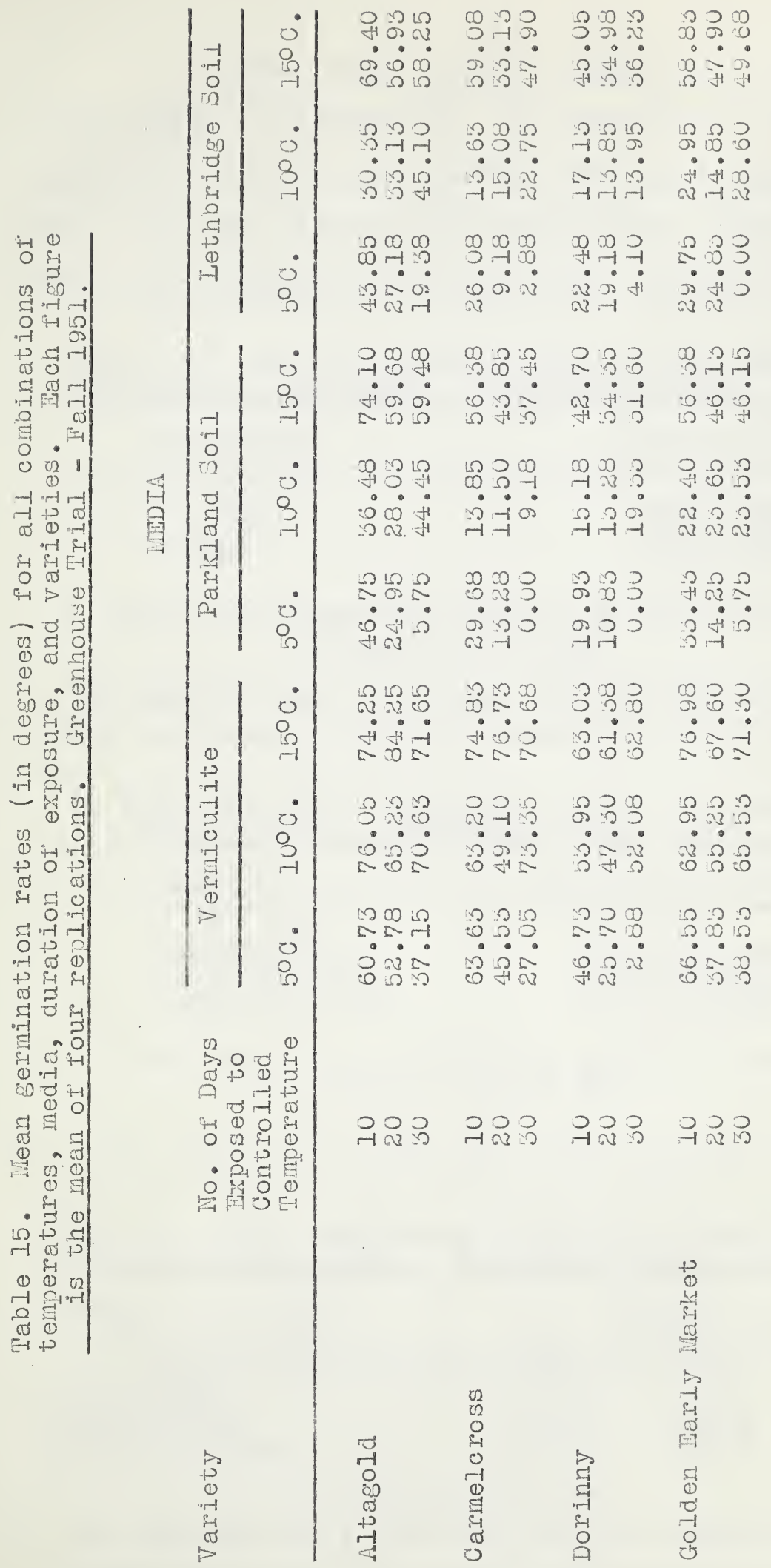



Liedia, too, produced highly signilicant ditrerences in the rates of gemination. As illustrated in Table 17, germination rates were signiticantly lower in Lethbridge and Parkland Soils than that obtained ror Vermiculite. rihere was no apparent diflerence between the eflects or the two soil types.

Mable 16. Ifean gemination rates (in degrees) for all temperature treatments. Greenhouse Prial - Fall 1951

Temperature

$$
\begin{aligned}
& 5^{\circ} \mathrm{C} . \\
& 10^{\circ} \mathrm{C} . \\
& 15^{\circ} \mathrm{C} .
\end{aligned}
$$

Germination Rate

26.07 degrees

35.25 degrees

56.69 degrees

Least Signiticant Dirrerence $= \pm 12.19$ degrees P value $=25.59$ tiet

Ixceeds the I per cent level of significance

Table 17. Nean germination rates (in degrees) for all media. Greenhouse Prial - Pall I95I

\begin{tabular}{ll} 
Ledium & Germination Rat \\
\hline Vemiculite & 58.20 degrees \\
Parkland Soil & 30.54 degrees \\
Lethbrige Soil & 29.27 degrees
\end{tabular}

Least signiricant Difference $= \pm 12.19$ degrees P value $=27.69$ ite

Exceeds the 1 per cent level of significance

Tabie 18. liean gemination rates (in cegrees) for aII ternerature and media. Greenhouse Mrial - Fall 1951

Hedium

Temperature

\begin{tabular}{llll} 
& $3{ }^{\circ} \mathrm{C}$. & $100 \mathrm{C}$. & $15^{\circ} \mathrm{C}$. \\
\hline Vermiculite & 42.09 & 61.22 & 71.29 \\
Parkland Soil & 17.05 & 21.74 & 49.02 \\
Lethoridge Soil & 19.07 & 22.78 & 49.77
\end{tabular}

F value $=40.76$

Exceeds the 1 per cent level ot signiticance 
The interaction Detween temperature and media was again highy significant, indickting a diIterential eIrect or temperature in direrent media. In Table 18 and Figure 24 it may be observed that the gemination rate aropped nore marrediJ from $15^{\circ} \mathrm{C}$. to $10^{\circ} \mathrm{C}$. in the two soils than in the verniculite nedium. The duration of exposure, alone, was not round to have any signiricant eỉect upon the germination rate (Mable 19), but its interaction with temperature was hishiy significant, indicating that the duration of exposure affected the reaction of the seed to the temperature treatments. Mable 20 and Figure 25 illustrate how germination at $5^{\circ} \mathrm{C}$. dropped shamply as duration oI exposure lengthened, whlle at $10^{\circ} \mathrm{C}$. germination dropped Slightly atter 20 days exposure and then increased rather sharply arter 30 days exposure.

Table 19. Mean germination rates (in degrees) or duration of exposure. Greenhouse Mrial - FalI 1951

Number of

Days Mxposed Gemination Rate

10

20

30
46.4 degrees

56.75 degrees

34.87 degrees

F value $=1.69$

Table 20. Nean gemination rates (in degrees) for all combinations of auration of exposure and temperature Greenhouse Trial - Fal1 1951

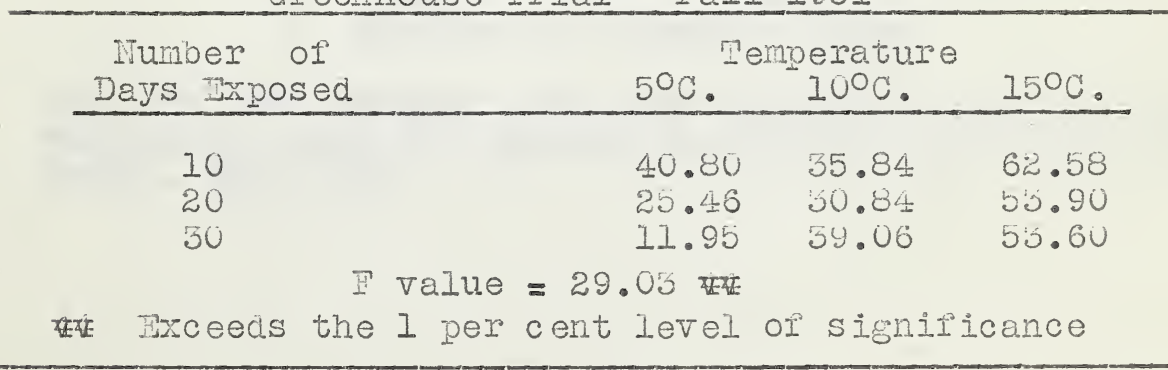




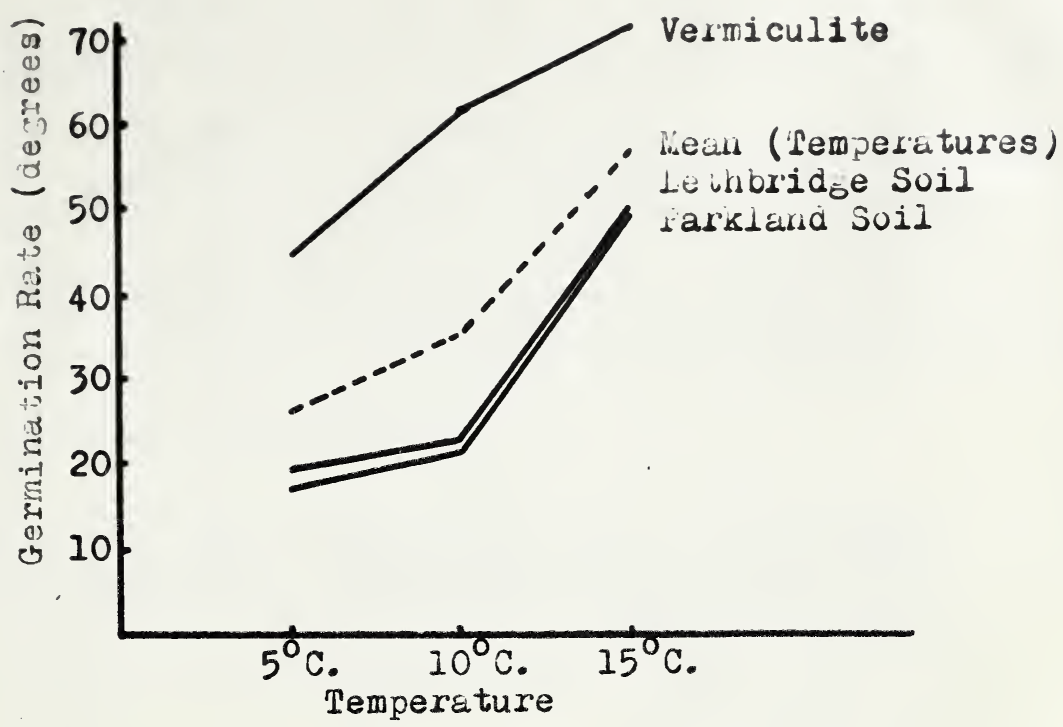

Fig. 24. The combined effect of temperatures and media upon the germination rate of sweet corn. Greenuouse Trial - Fall 1951.

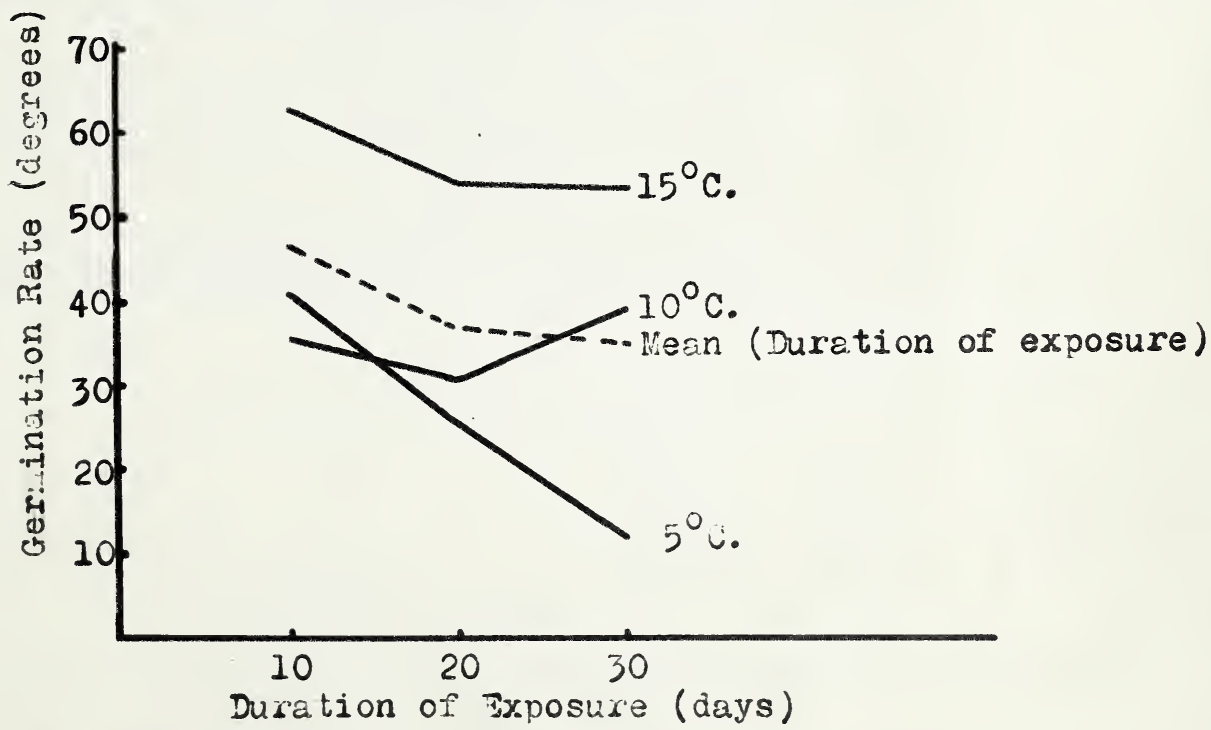

Fig. 25. The combined effect of duration of exposure and temperature upon the germination rate of sweet corn. Greenhouse Trial. - Fall 195]. 

Signiricant dirferences were also observed between the germinating ability of the four varieties in the trial (Mable 2l). Altagold geminated signiticantly better than any of the other three varieties, while Dorinny germinated at a signiricantly lower rate than the other three. No dirlerence between the gemination rates ot Cameleross and Golden Sarly liarket could be established.

Mable 21. Nean gernination rates (in degrees) for varieties. Greenhouse Trial - Fal1 1951

Variety

Altagold

Carmelcross

Dorinny

Golden Farly Nariset
Germination Rate

50.22 degrees

56.64 degrees

50.00 àegrees

40.49 degrees

Least Signiricant Difrerence $= \pm 6.58$ degrees P value $=19.62$.

Ixceeds the 1 per cent level of significance

Table 22. Nean gemination rates (in degrees) of varieties at all temperatures. Greenhouse Trail - Fall 1951

Variety

Temperature

\begin{tabular}{llll} 
& $50^{\circ} \mathrm{C}$. & $10^{\circ} \mathrm{C}$. & $15^{\circ} \mathrm{C}$. \\
\hline Altagold & 35.39 & 47.72 & 67.55 \\
Carmelcross & 24.41 & 30.21 & 55.56 \\
Dorinny & 16.86 & 27.34 & 45.79 \\
Golden Darly larlet & 27.38 & 35.72 & 57.88 \\
F value $=1.00$ & & &
\end{tabular}

The effect of temperature upon the gemination or the four varieties or sweet com are iliustrated in Table 22 and in Figure 26. The insigniIicant $P$ value indicates that the 


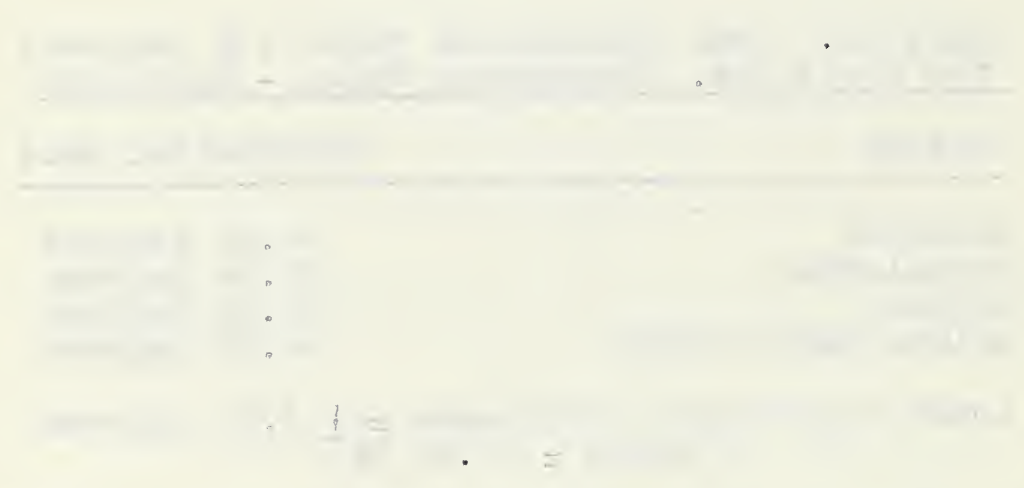

4

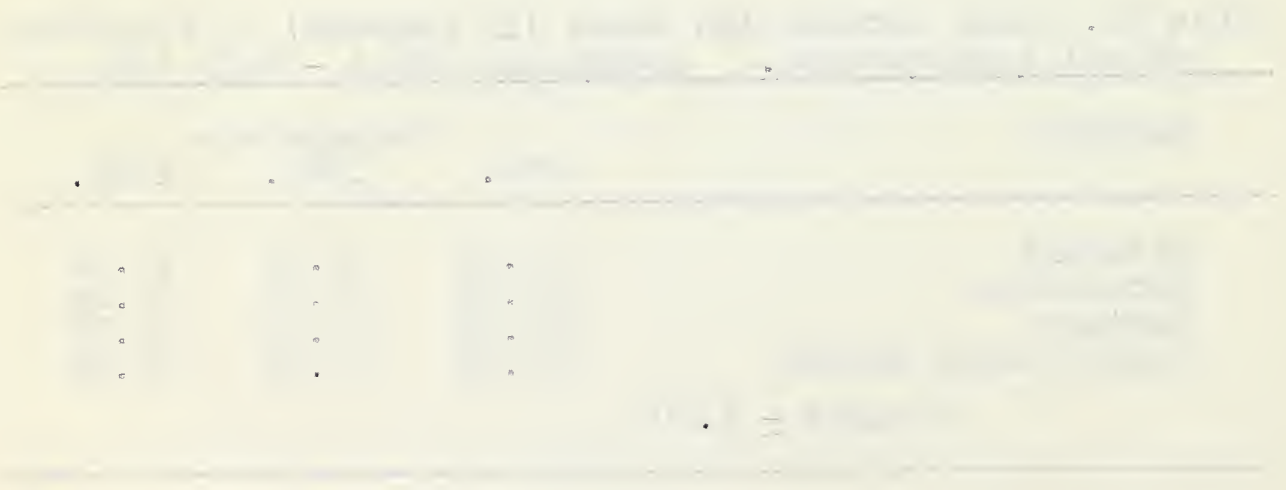


varieties responded similarly to temperature treatment. The graph in rigure 26 bears this out more enphatically.

The nature of the germinating nedium significantly influenced the germination of the different varieties. Table 25 and Figure 27 shows that the reduction in gerinination in soils, as compared to vermiculite, was greatest ror the variety Camelcross and least for Altagold. Gemination of lamelcross was reduced by nearly two-thirds, that of Altagold by approximately one-third, and those of Dorinny and Golden Larly Harket by approximately one-half.

Table 23. Nean germination rates (in àegrees) of varieties as aliected by the germinating mediun Greenhouse Trial - Fall 1951

Variety

Mediunn

Vermiculite Parkland Lethbridge

\begin{tabular}{llll} 
& & Soil & SOII \\
\hline Altagold & 65.86 & 42.18 & 42.62 \\
Camelcross & 60.48 & 23.91 & 25.52 \\
Dorinny & 46.20 & 20.80 & 22.99 \\
Golden Harly Market & 60.25 & 30.18 & 31.04
\end{tabular}

$$
\text { F value }=3.49
$$

Freeds the 5 per cent level of significance

In order to better evaluate the errects of temperature upon the gernination of sweet com, a separate analysis of variance was computed for the data obtained Ior the seed geminated in Vemiculite. The complete analysis of variance is tabulated in Appendix IV. 



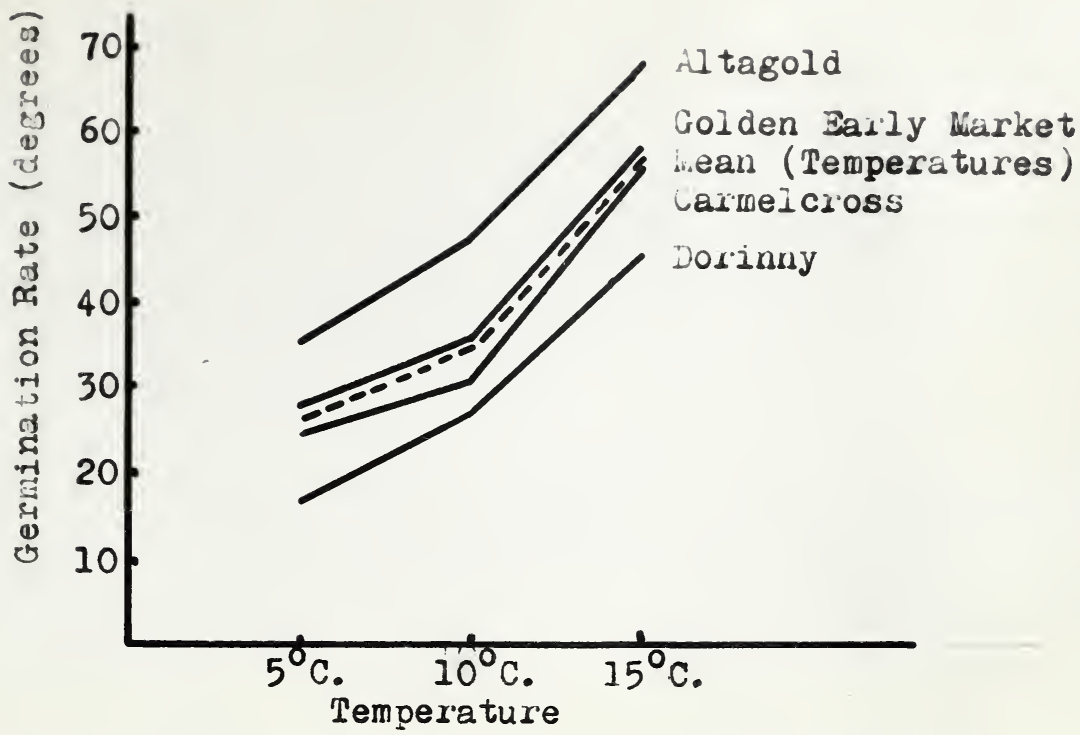

Fig. 26. The effect of tempercture upon the germination of four varieties of sweet corn. Greenhouse Trial - Pall.1951.

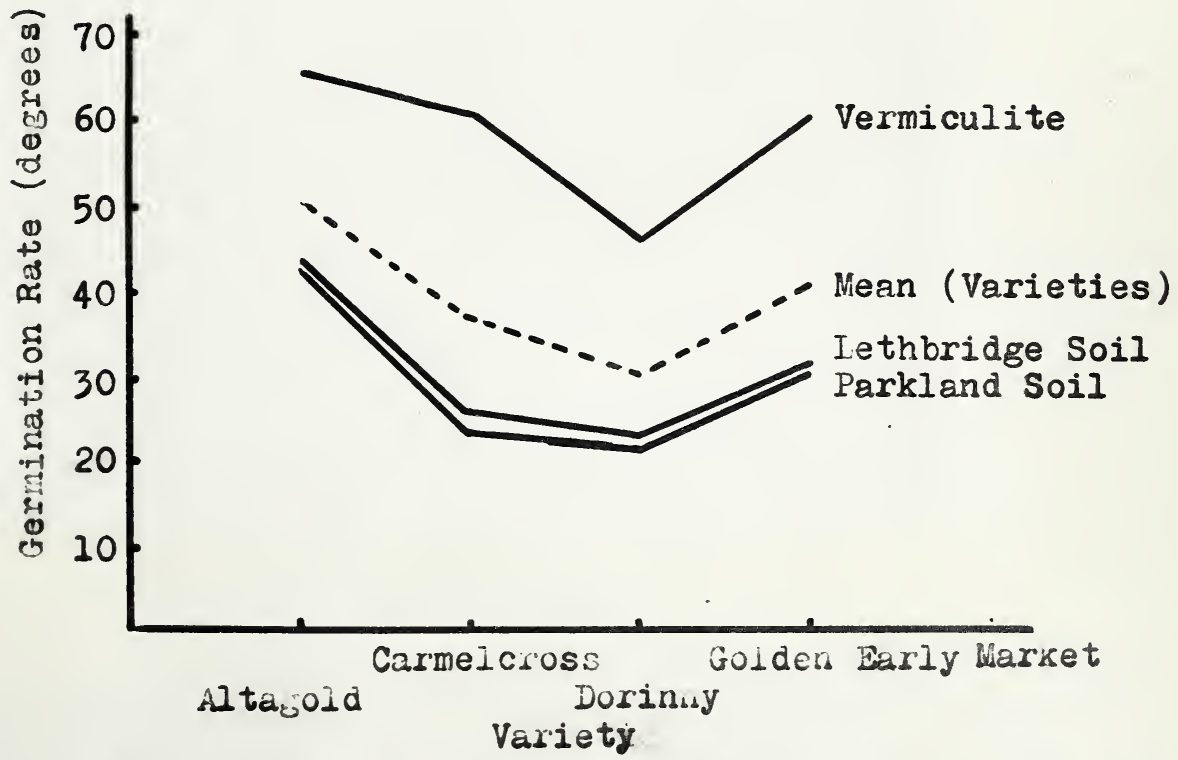

Fig. 27. The efiect of medium upon the germination rate of four varieties of sweet corn. Greenhouse Trial - Pall 1951. 

Teinperature again caused signiricant ditrerences in the germination of sweet corn. Ilean germination rates ror the ditierent germinating temperatures are listed in lable 24. Aplying the least signiticant ditierence it is observed that gernination was significantly reduced with each decrease in germination temperature.

Mable 24. Hiean germination rates (in aegrees) for sweet corn germinated in verniculite at dirterent temperatures Greenhouse Trial - Fal 1951

remperature

$$
\begin{aligned}
& 5^{\circ} \mathrm{C} . \\
& 10^{\circ} \mathrm{C} . \\
& 15^{\circ} \mathrm{C} .
\end{aligned}
$$

Germination Late

$$
\begin{aligned}
& 42.09 \text { degrees } \\
& 61.22 \text { degrees } \\
& 71.28 \text { degrees }
\end{aligned}
$$

Least Significant Difterence $=\frac{t}{1} 4.26$ degrees I value $=145.81$ tit

Fxceeds the 1 per cent level of significance

Varieties diliered significantiy ( $I=40.47$ in their germinatins ability, and, as berore, the germination at the different temperatures was differentially afrected by the duration of exposure, $(\mathrm{F}=25.59$. The interaction between varieties and temperatures vas again insigniilcant ( $F=2.18$ ) verifying the observation that the varieties diu not react difierentIy to temperature treatment.

Note: In each of Figures 28 to 33 the quaduplicate rows of varieties appear in the following rotation: Front row ( I to $r$ ) - Altagold, Carmelcross, Dorinny, Golden Early Market exposed for 30 days; and Altagold and Carmelcross exposed for 20 days. Back row ( 1 to ir) - Dorinny, Golden Early Market exposed for 20 days; and Altagold, Camelcross, Dorinny and Golden Early Market exposed for 10 days. 



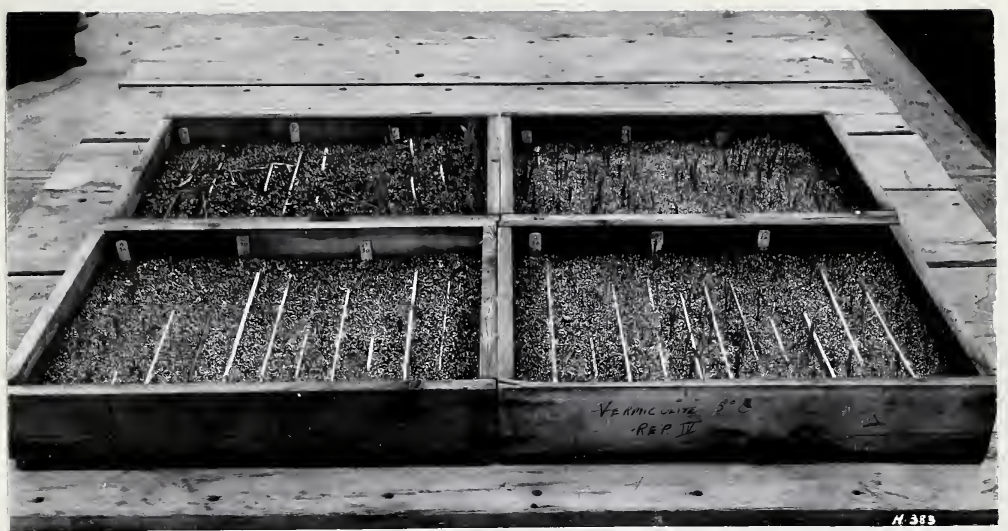

Fig. 28

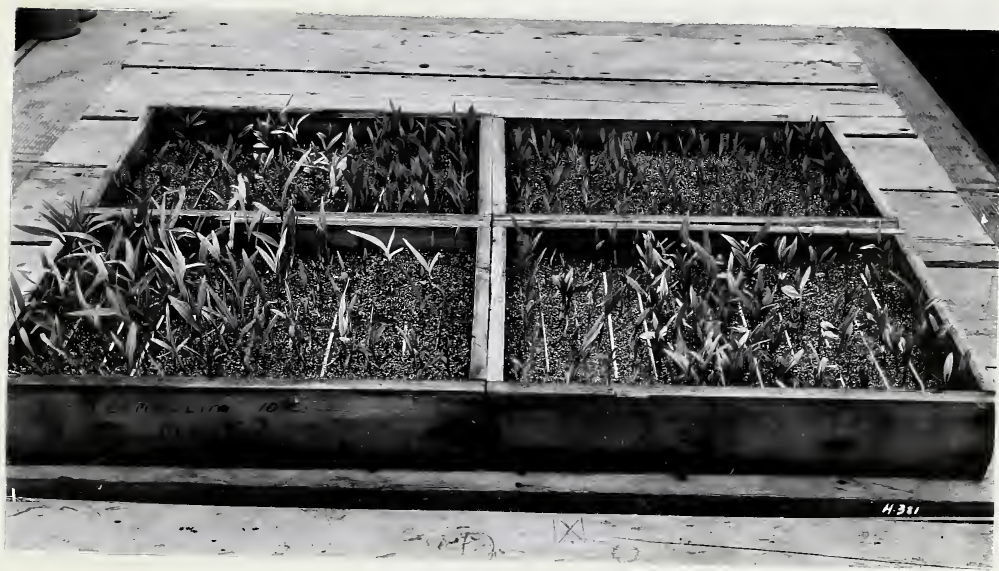

Fis. 29

Figures 28 and 29. The germination of steet corn seed in Vermiculite, snowing the efiects of temperature and duration oI exposure after seven days in the greenhouse Greenhouse Irial - HaII I95I. Fig. 28 exposed at 50 C. and $\mathrm{Fig} .29$ at $1 \mathrm{O}^{\circ} \mathrm{C}$. Note also varietal effects (see footnote p. 46 ). 



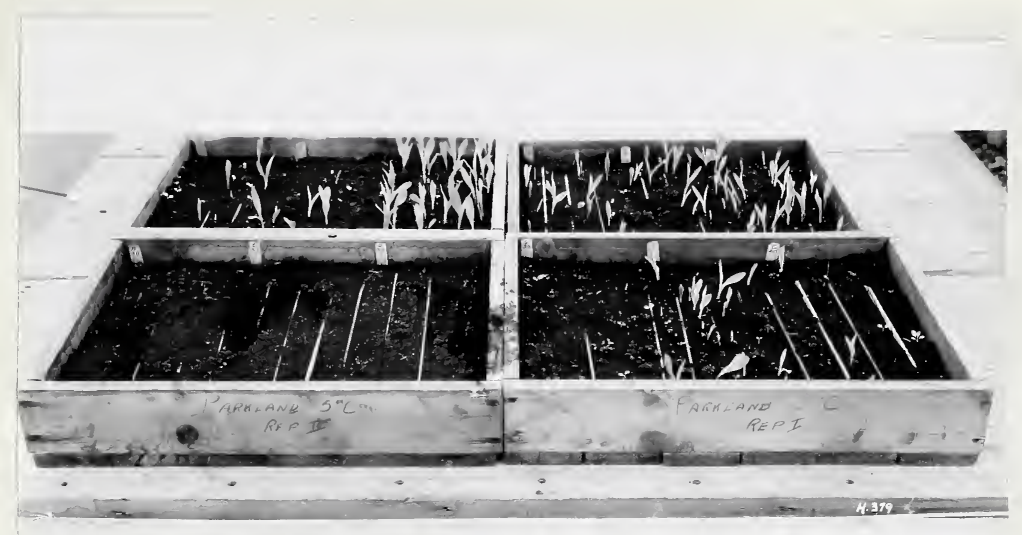

I'ig. 30

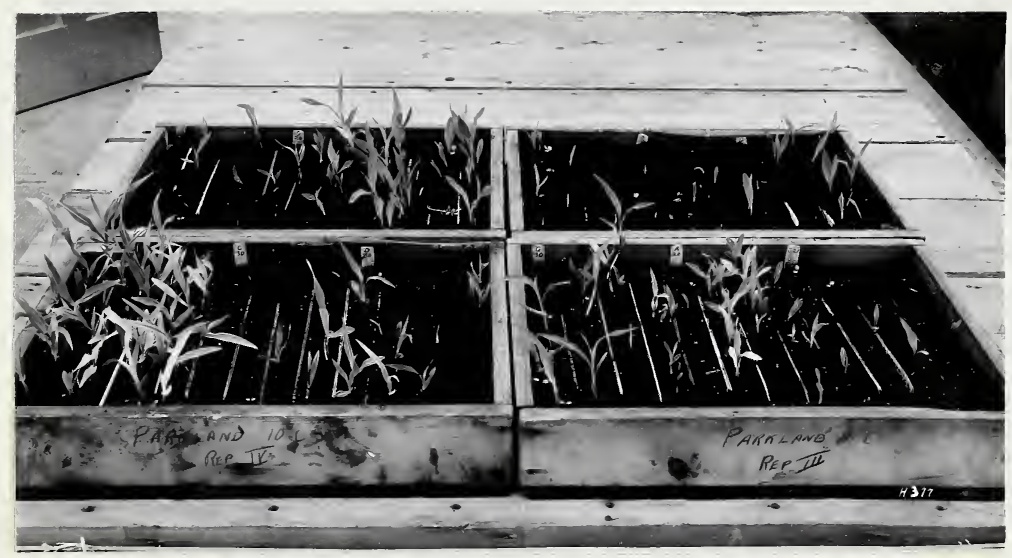

Fis. 31

Eigures SU and 31 . The gemination oI steet corn seed in Parkland Soil, showlng the eliects of tenperature and duration oI exposure aiter seven days in the greenhouse. Greenhouse Prial - Fa.1 1951. Fig. 50 exposea at $5^{\circ} \mathrm{C}$. and $1 \mathrm{~g} \cdot 31$ at $10^{\circ} \mathrm{C}$. Note also varietal effects (see footnote p. 46 ). 


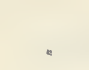




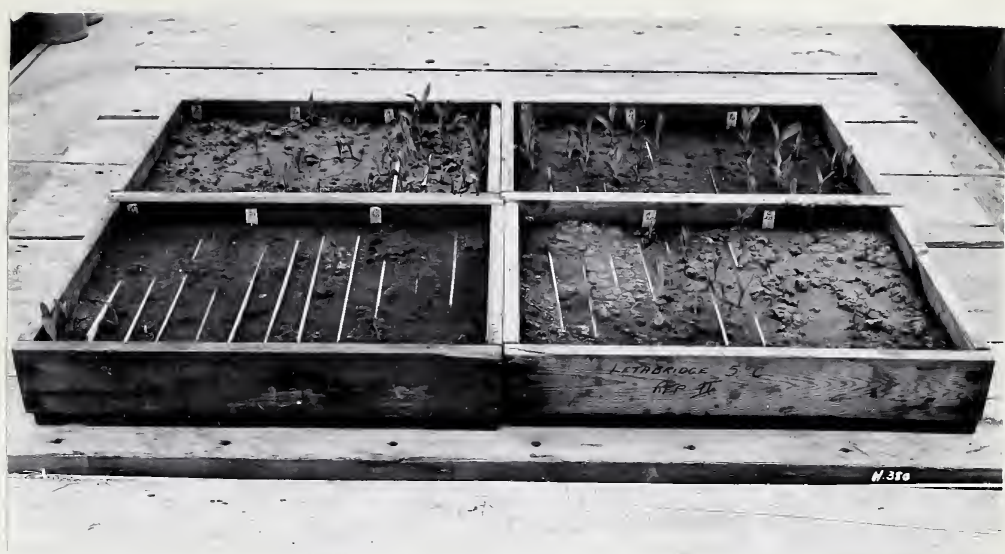

Fig. 32

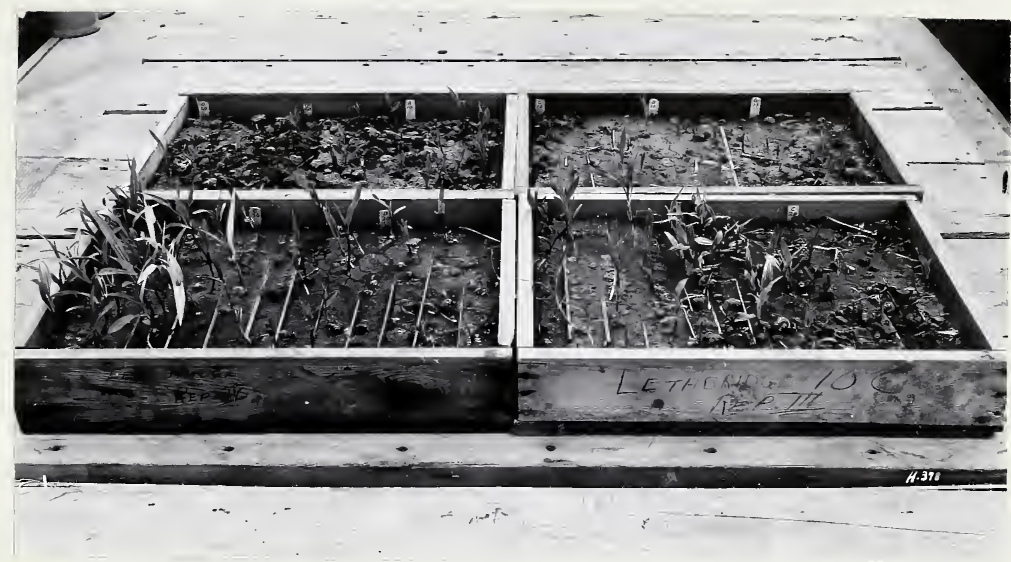

Fis. 35

Figures 52 and 53. The gemination of sweet corn seed in Lethbridge Soli, showing the efiects of temperature and ouration oi exposure atter seven days in the greenhouse. Greenhouse lrial - 1911 1951. Pig. 52 exposed at $5{ }^{\circ}$, and $\mathrm{Fis}$. 30 at $1 \mathrm{U}^{\circ} \mathrm{C}$. Note also varietal effects (see foctnote p. 46 ). 



\section{DISCUSSION OI RTSUIMS}

Mhe germination ois sreet com was signii icant reduced by the lowering ot the soil terperature tron $15^{\circ} \mathrm{C}$. to IUOC. There was, however, no signiricant reduction in germination when the temperature was reduced rrom IU $\mathrm{O}^{\mathrm{C}}$ 。 to 50C. or I. $7^{\circ} \mathrm{C}$. It is apparent, therejore, that tne ninimum temperature, at which germination and growth or sweet corn will take place actively, is above $10^{\circ} \mathrm{C}$, and below $15^{\circ} \mathrm{C}$. Similar observations were recolded by Lehenbauer (12), Imin (3), and Wagoon and Culpepper (13). The results ol this experiment indicate that the temperature range used vas too wide to determine a minimun growth temperature, although the Iover temperatures might be used satistactorily in evaluating the cold hardiness ot inbred. Iines or stieet com, as recommended. by other worlers $(5,7,9,16,17,18)$. Further studies are plannea in which a range of temperatures betreen 1000 , and $15^{\circ} \mathrm{C}$. will be used to determine the minimum growth temperature of sweet corn. In the 1950 Field Mrial, it was observed that the nean germination rate at I0 $0^{\circ}$. was silghiy lower than the mean germination at $b^{\circ} \mathrm{C}$. (Figure 16 and Lable 2 ). Mis relationship was most pronounced in the case of seed germinated in Parl-land Soil (Table 4). Haskell (5) recorded similar results. As an assumption, one might feel that the Parkland Soil suported the largest population of hamiul parasitic organisms, and these night Iogically be more active at the hisher temperature. The greenhouse trials failec to confirn the above observations, resulting in rather inconclusive results on this point. 

That the nature of the gerininating mediun al'íected the gerination of sweet corn, as reported by Haskell (7), was confirned in the trials reported in this paper. Germination in the soils was much lover than it vas in sterile vermiculite. This was particularly true at the two lower temperatures, as illustrated in Figures 16, 22, and 24. These observations suggest strongly that the reduction or germination in soils at low temperatures is, as reported by Haskell (5), due partly to the direct effects of cold and partiy to the detrimental erfects of soil pathogens. Ihe seed exposed to the $10^{\circ} \mathrm{C}$. temperature showed a greater incidence of moulded kernels than did the seed exposed to $5^{\circ} \mathrm{C}$. Where only the gemination in vermiculite was considered (Table 24) germination vas reduced progressively as temperatures becane lower, with greatest reduction Irom $10^{\circ} \mathrm{C}$. to $5^{\circ} \mathrm{C}$. It is, therefore, logical to assune (as indicated. earlier) that the reduction in germination at $5^{\circ} \mathrm{C}$. is due, largely, to the destruction of the embryo by direct effect OI cold, and at $10^{\circ} \mathrm{C}$. by the penetration oI soil pathogens into the damaged seeds and slowly developing coleoptiles.

Since the duration of exposure to controlled temperatures was lound to be signiricant in only one trial, it must be assumed that it was not important, in itself, in detemining stands. It did, hovever, appear to bear a signiticant relation to stands at the lower temperatures, as illustrated in Figures 17 and 23, where marked decreases vere observed as the duration ol exposure lengthened. Faskell (5, 7) recorded similar results. 

Other worlers (5, 7, 9, 16, 17) have reported that inbred lines and hybrids react differently to cold treatment, with some inbreds being more cold resistant than others. They observed, too, that the hybrids generally possessed greater cold resistance than their parent lines. In this project, significant ditierences were obtained between varieties in all trials. The sane varieties did not alvays occupy the same position in relation to high or low gemination. When compared under the different temperature treatments, it was observed that all varieties reacted similarly to each temperature within a trial (Figures 20 , 2I, and 26). It appears Iogical to conclude that varieties dilIered only as the relative geminating ability or the lots of seeds aiftered. The differences could be explained on the basis of maturity, as has been discussed by Rush and NeaI (19). The similarity of the reactions of all varieties to temperature treatment may be due, to some extent at least, to the fact that all were varieties requiring a relatively short groving season. A late season variety, such as Iochief, Iincoln, or Lee, nay have reacted direrentIy to cold treatment.

On the basis of the maturity data obtained from the 1950 Field Trial, it was not possible to distinguish any differences in maturity as affected by gemination, temperature and/or duration or exposure, within a variety. There was some variation in date of silking but this was not consistent for each treatment. It seened reasonable to assume that sweet corn gerninated at $15^{\circ} \mathrm{C}$. would mature earlier than that germinated at the lower temperatures because plants were better developed at 

planting out time. These plants suifered a severe setbach, as mentioned earlier, and at silking time vere at the sane stage oI naturity as those geminated at the lower temperatures. If the seed had been sown in plant bands it is probable that the transier might have been made wiuhout serious injury to the seedings, thus making ror a more reliable field trial. whe plants grom trom seed gerninated at $15^{\circ} \mathrm{C}$. were somewhat taller than those germinated at the lower terperatures. Similar diterences were observed by Haskell (8) who noted also that the taller plants produced fewer tillers and lower plant yields than the shorter plants. In the project, reported herein, there was no apparent oitrerence in the number of tillers on the plants irom the dirierent temperature treatments. Unfortunately, no harvest was realized and no comparison could be nade of the effect of temperature treatment upon yield. 



\section{SUIHIARY}

1. A series oi trials were conducted during I9bo and 1951. The efiects of the following ractors, upon the gernination ot' three open-pollinated valieties (Altagold, Dorinny, and Golden darly warliet) and one hybrid (Carnelcross) or sweet corn, were studied:

(a) Controlled temperatures - 50 ., 1000., and 150 C. (except in one trial when 1.700., 100 , and 18.30 (vere used);

(b) Germinating nedia - Vermiculite, Parkiand soil, and Lethbridge Soil;

(c) Duration of exposure - 10, 20, and 30 days.

2. Jach trial was laid out as a split-plou ractorial.

5. The percentage data vere transtomed by means or the angular transiomation and vere anaiysed statistically.

4. Highly signiticant ditrerences were observed betreen the highest temperature treatnent and the lower ones in each trial. This was more pronounced in soils and under ditferent aurations or exposure.

5. Germination was signiricantly better in Vermiculite than in either of the soils used.

6. The duration of exposure was important only at the two Lower temperatures oI each trial, when increased exposure caused. signiticant reductions in gemination.

7. The gerinination rates or the diferent varjeties ailierea significantIy, out aII reacted similarly to temperature treatment. 


\section{CONCLUSIONS}

The tollowing observations have been wade on the basis of the results obtained from the experiments described elsewhere in this thesis:

1. Temperatures $01^{\circ} 10^{\circ} \mathrm{C}$. or lower caused signiricant reductions in the gernination of sweet corn. There was no apparent difterence between the effects upon germination of $10^{\circ} \mathrm{C}$. and of the lower temperatures studied.

2. Germination in soil was signiricantIy lower than in sterile vermiculite, particularly at the lower temperatures, indicating the importance of soll pathogens in liniting the stands of sweet com at low temperatures. This could be overcome, to some extent, by seed treatnent.

3. The overall effect or duration of exposure did not appear to be important in determining the stands of sweet corn. However, when considered in relation to temperature, the duration of exposure had a highly signiticant elfect, causing narkedy reduced germination at the lower temperatures but not at $15^{\circ} \mathrm{C}$ 。

4. Varieties were found to difer signiricanty in their ability to germinate. Mone showed any diferential eriect due to temperature treatnent or to duration or exposure. The differences observed must be considered to be related. to the viability and to possible cifrerences in naturity oI the several seed lots used. 


\section{ACIINOVLIDDGINANTS}

The author vishes to acknowledge his indebtedness to the rollowing individuals whose assistance was greatly appreciated: Dr. R.J. Hilton ror constant advice throughout the progress of this study and for constructive criticism in the preparation of this thesis; Dr. H.B. Cannon for outlining the experimental design and statistical analysis utilized in this study; Lir. I.I. Nonnecke for constant interest, encouragement, and assistance; Dr. V.C. Broadioot, and other nembers of the stafr of the Science Service Laboratories, Lethiridge, Hiberta, for the use of controlied temperature and greenhouse Iacilities; IIIss R. Vander Lelie who diligently typed the manuscript; and all students and techniciens who in any way assisted with this study. 



\section{BIBLIOGRAPHY}

I. BeII, G.D.H. The ertect oI low temperature grain pretreatment on the development, Jield and grain oi some varieties of wheat and barley. J. Lgr. Sci.27:577393.1937.

2. Dickson, J。G。 and Holbert, J.R. The intluence of temperature upon the metabolism and expression or disease resistance in selfed lines of com. J. An. Soc. Agron. 18:314-32:. 1926.

3. Mrwin, E.T. Clinatic and varietal tactors in pumplin procuction. Canner 68(10, pt. 2):71-72. 1929.

4. Haskell, G. Cold hardiness and seed shape in maize. IVature 163:907. 1948.

5. Haskell, G. affect of low temperature on the gemination of inbred lines of sweet corn. Science 107:150. 1948.

6. Haskell, G. Presoaking and cold hardiness in maize. PIant and Soil 1:342-345. 1949.

7. Haskell, G. Studies with sweet corn: I. Cold treatment and gemination. Plant and Soil $2: 49-5 \%$. 1949 .

8. Haskell, G. Studies vith sweet corn: II. Sowing dates

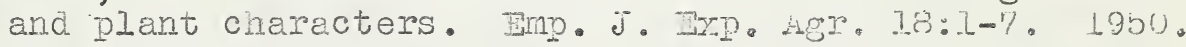

9. HaskelI, Go and Iingleton, T.R. Use of controlled low teinperature in evaluating the cold hardiness or inired and hybrid maize. Agron. J. $41: 54-40$. 1949.

10. Hayes, H.K. and Immer, H.R. Methods oI Plant Breeding. IncGraw-Hil Book Co. Inc。, New York. 1942.

11. Jones, J.:. Gemination of rice seed as alfected by temperature, rungicides and age. J. Ln. Soc. Agron. $18: 576-592$. 1926.

12. Lehenbauer, P.A. Growth of maize seedings in relation to temperature. Physiol. Researches 1:247-288. 1914.

15. Magoon, C.A. and Culpepper, C.II. Response or sweet corn to varying temperatures from planting to canning maturity. U.S.D.A. Tech。BuII. 312. 1932.

14. Iather, $\mathbf{I}$. and Haskell, G. Breeding cold hardy sweet corn in Britain. J. Agr. Sci. 59:56-63. I949. 

15. Neyer, B.S. and hinderson, D.B. Plant Fhysiology. D. Van Nostrand Co. Inc., Moronto. 1949.

16. Hortimer, C.G. Gea mays geruination reaction under cold test conditions. Doin. Hxp. sta. Harrow, Ont., Seminar Lbstracts Jxp. Fam Service. 1949-50.

17. Pinnell, E.L. Genetic and environnental tactors aftecting corn seed gernination at low temperatures. fgron. J. $41: 562-568$. 1949。

18. Robbins, J.J. and Petsch, I. H. loisture content and high temperature in relation to gernination o: corn and weat grains. Botan. Gaz. 95:85-92. 1952.

19. Rush, G.P. and Neal, M.P. rhe elfect or maturity and other ractors on stanōs of corn at low temperatures. Agron. J. 45:112-116. 1951.

20. Matum, I.A. and Zuber, 1i.S. Germination of naize under adverse conditions. J. Sili. Soc. Agron. 35:48-59. 1943.

21. Vander Heulen, $\mathrm{Z}$. and Henke, $\mathrm{H}$. Cold testing of corn. Seed World 63:8-10. 1948.

22. Vilson, H. I. Theat, soybean, and oat gemination studies with particular reference to temperature relationships. J. th. Soc. Agron. 20:599-619. 1928.

23. Wilson, H.I. and Hottes, C.P. Wheat gemination studies with particular reterence to temperature and noisture relationships. J. An. Soc. Agron. 19:181-190. 1927. 

PPITDIX I

MIIYSIS OF VARIATCE - PIILD RAIAI 1950

\begin{tabular}{|c|c|c|c|c|}
\hline $\begin{array}{c}\text { Variance } \\
\text { due to }\end{array}$ & D.F. & $\begin{array}{l}\text { Sums of } \\
\text { Squares }\end{array}$ & $\begin{array}{l}\text { Ilean } \\
\text { Square }\end{array}$ & $\mathrm{P}$. \\
\hline \multicolumn{5}{|l|}{ VHOLE PLORS: } \\
\hline $\begin{array}{l}\text { Replicates } \\
\text { Temperatures } \\
\text { Iedia } \\
\text { T xiI } \\
\text { Error (a) }\end{array}$ & $\begin{array}{r}3 \\
2 \\
2 \\
4 \\
24\end{array}$ & $\begin{array}{r}1821.69 \\
17508.35 \\
85255.67 \\
3574.20 \\
7526.24\end{array}$ & $\begin{array}{r}607.23 \\
8754.17 \\
41627.84 \\
895.72 \\
315.59\end{array}$ & $\begin{array}{r}1.95 \\
9.79 \\
46.57 \\
2.85\end{array}$ \\
\hline \multicolumn{5}{|l|}{ SUB-PIONS: } \\
\hline 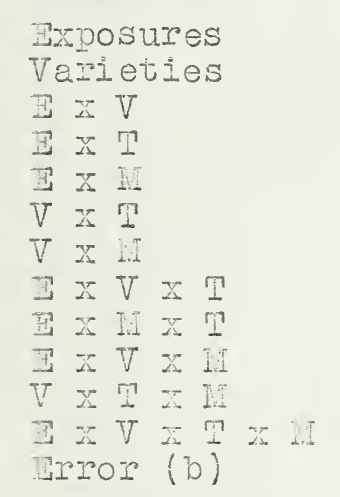 & $\begin{array}{c}2 \\
3 \\
6 \\
4 \\
4 \\
6 \\
6 \\
12 \\
8 \\
12 \\
12 \\
24 \\
297\end{array}$ & $\begin{array}{r}27642.17 \\
15222.35 \\
733.80 \\
4796.45 \\
1227.12 \\
355.74 \\
3024.59 \\
752.62 \\
769.58 \\
1404.77 \\
1543.66 \\
2515.53 \\
1995 \% .74\end{array}$ & $\begin{array}{r}13821.09 \\
5074.11 \\
122.30 \\
1199.11 \\
306.78 \\
59.29 \\
504.07 \\
65.55 \\
96.20 \\
117.06 \\
111.97 \\
104.72 \\
67.20\end{array}$ & $\begin{array}{c}11.53 \\
10.07 \\
1.17 \\
11.59 \\
2.95 \\
0.57 \\
4.81 \\
0.61 \\
0.92 \\
1.12 \\
1.07 \\
1.56\end{array}$ \\
\hline
\end{tabular}

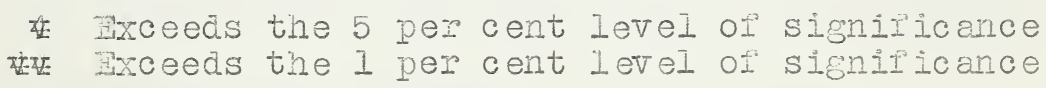

Calculations of Least Signiticant Ditierences:

L.S.D. $=\frac{2\left(s^{2}\right)}{k}(t .05)$

I.3.D. (Menperature and Hedia) $=(3.52)(2.770)= \pm 9.77$ degrees

I. D. (Exposures) $=(4.08)(2.7 \overline{7} 6)=\frac{1}{7} 11.55$ degrees

L.D.D. (Varieties) $=(3.06)(2.447)=\frac{7}{7} 7.49$ degrees 


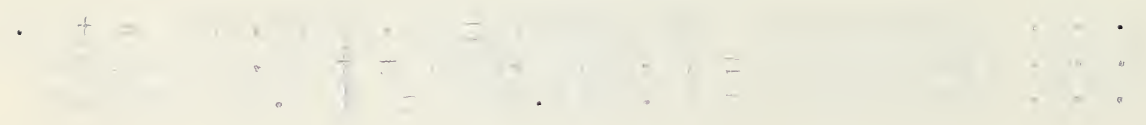


PPINDI II

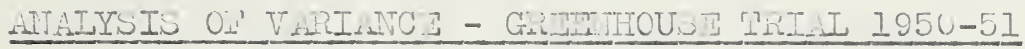

\begin{tabular}{|c|c|c|c|c|c|}
\hline $\begin{array}{l}\text { Variance } \\
\text { due to }\end{array}$ & ". D. . & $\begin{array}{l}\text { Suns oI } \\
\text { Squares }\end{array}$ & $\begin{array}{l}\text { wean } \\
\text { square }\end{array}$ & \multicolumn{2}{|l|}{ I. } \\
\hline MOIE PLOMS: & & & & & \\
\hline $\begin{array}{l}\text { Ieplicates } \\
\text { Iemperatures } \\
\text { liedia } \\
\text { I x I: } \\
\text { Irror (a) }\end{array}$ & $\begin{array}{r}3 \\
2 \\
2 \\
4 \\
24\end{array}$ & $\begin{array}{r}43.74 \\
169861.07 \\
40360.64 \\
18167.24 \\
5312.87\end{array}$ & $\begin{array}{r}15.58 \\
84950.54 \\
25180.32 \\
4541.81 \\
221.37\end{array}$ & $\begin{array}{r}0.01 \\
18.70 \\
5.10 \\
20.52\end{array}$ & WE: \\
\hline \multicolumn{6}{|l|}{ SUB-IOIS: } \\
\hline 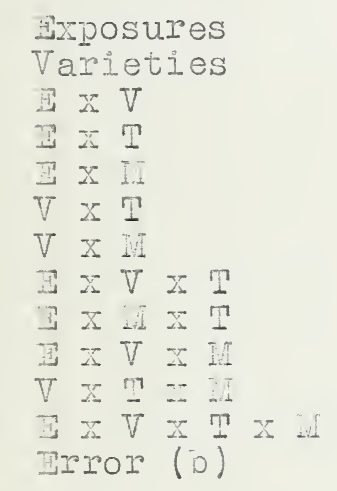 & $\begin{array}{r}2 \\
3 \\
6 \\
4 \\
4 \\
6 \\
6 \\
12 \\
8 \\
12 \\
12 \\
24 \\
297\end{array}$ & $\begin{array}{r}13519.90 \\
11691.00 \\
609.45 \\
5134.75 \\
1479.35 \\
1523.59 \\
3572.59 \\
955.02 \\
1885.54 \\
612.15 \\
2738.19 \\
1140.45 \\
13146.59\end{array}$ & $\begin{array}{r}6759.95 \\
3897.02 \\
101.57 \\
1285.69 \\
369.84 \\
250.90 \\
595.40 \\
79.59 \\
235.44 \\
51.01 \\
228.18 \\
47.52 \\
44.26\end{array}$ & $\begin{array}{r}5.27 \\
17.09 \\
1.28 \\
5.45 \\
1.56 \\
1.11 \\
2.01 \\
1.80 \\
5.32 \\
1.15 \\
5.16 \\
1.07\end{array}$ & 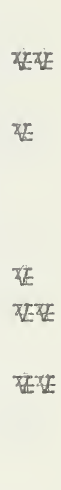 \\
\hline
\end{tabular}

Jxceeds the 5 per cent Ievel of significance
Ixceeds the 1 per cent Ievel ol significance

Ieast Signisicant Diprerences:

I.S.D. (nemperatures) $=(8.151)(2.776)= \pm 22.63$ dejrees L.3.D. (Varieties) $=(\overline{2} .06)(2.179)= \pm 4.49$ degrees 



\section{PPPIDII III.}

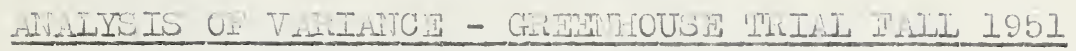

\begin{tabular}{|c|c|c|c|c|c|}
\hline $\begin{array}{l}\text { Variance } \\
\text { due to }\end{array}$ & D. E. & $\begin{array}{l}\text { Sums ot } \\
\text { Squares }\end{array}$ & $\begin{array}{l}\text { Hean } \\
\text { Zquare }\end{array}$ & $I^{\prime}$. & \\
\hline \multicolumn{6}{|l|}{ HOLE PLOTS: } \\
\hline $\begin{array}{l}\text { Replicates } \\
\text { Temperatures } \\
\text { Media } \\
\text { M w In } \\
\text { Mrrol (a) }\end{array}$ & $\begin{array}{r}5 \\
2 \\
2 \\
4 \\
24\end{array}$ & $\begin{array}{r}32.82 \\
71145.36 \\
76972.30 \\
5560.24 \\
818.45\end{array}$ & $\begin{array}{r}10.94 \\
35572.68 \\
38486.15 \\
1090.06 \\
34.10\end{array}$ & $\begin{array}{r}0.52 \\
25.59 \\
27.69 \\
40.76\end{array}$ & 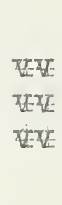 \\
\hline \multicolumn{6}{|l|}{ SUB-EIOIS: } \\
\hline 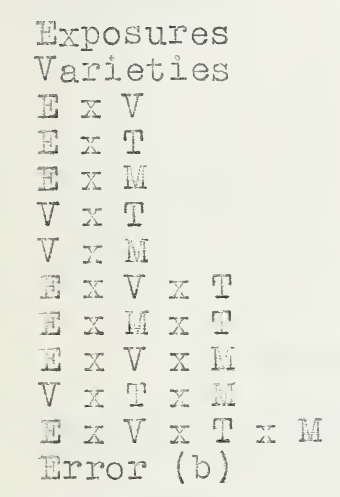 & $\begin{array}{r}2 \\
3 \\
6 \\
4 \\
4 \\
6 \\
6 \\
12 \\
8 \\
12 \\
12 \\
24 \\
297\end{array}$ & $\begin{array}{r}11046.59 \\
23145.96 \\
260.48 \\
15089.59 \\
255.62 \\
679.68 \\
2559.15 \\
381.71 \\
1722.45 \\
1575.42 \\
1720.59 \\
2705.44 \\
5055.95\end{array}$ & $\begin{array}{r}5523.30 \\
7715.52 \\
45.41 \\
3272.40 \\
65.41 \\
115.28 \\
590.19 \\
51.81 \\
215.31 \\
114.62 \\
143.37 \\
112.75 \\
16.95\end{array}$ & $\begin{array}{r}1.69 \\
19.62 \\
0.39 \\
29.03 \\
0.59 \\
1.00 \\
3.49 \\
0.28 \\
1.99 \\
1.02 \\
1.27 \\
6.65\end{array}$ & 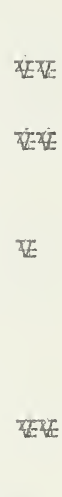 \\
\hline
\end{tabular}

* Ixceeds the b per cent level or signilicance Wxceeds the 1 per cent Level of signiticance

Least Signiticant Differences:

L.S.D. (Temperatures and Hedia) $=(4.39)(2.776)=$ I.S.D. (Varieties) $=(2.69)(2.447) \stackrel{ \pm 12.19 \text { degrees }}{ \pm} 6.58$ degrees 



\section{DWPUIDIV IV}

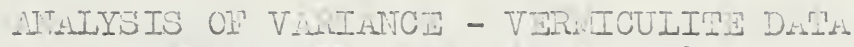
GLITIIOUST TILII I'II 1951

\begin{tabular}{|c|c|c|c|c|c|}
\hline $\begin{array}{l}\text { Variance } \\
\text { due to }\end{array}$ & D. . . & $\begin{array}{l}\text { Wuns ol } \\
\text { Suuares }\end{array}$ & $\begin{array}{l}\text { Lean } \\
\text { square }\end{array}$ & $\mathrm{I}^{\prime}$. & \\
\hline \multicolumn{6}{|l|}{ MHOIE LOTS: } \\
\hline $\begin{array}{l}\text { Lewlicates } \\
\text { lemperatures } \\
\text { Jrror (a) }\end{array}$ & $\begin{array}{l}5 \\
2 \\
6\end{array}$ & $\begin{array}{r}48.55 \\
21121.60 \\
434.59\end{array}$ & $\begin{array}{r}16.18 \\
10560.80 \\
72.40\end{array}$ & $\begin{array}{r}0.22 \\
145.81\end{array}$ & 证玨 \\
\hline \multicolumn{6}{|l|}{ SUB-1LOMS: } \\
\hline 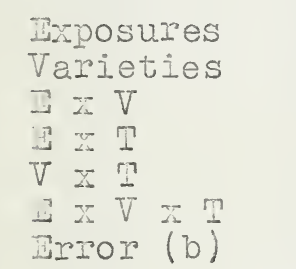 & $\begin{array}{r}2 \\
3 \\
6 \\
4 \\
6 \\
12 \\
99\end{array}$ & $\begin{array}{r}3667.66 \\
7653.46 \\
762.75 \\
6434.35 \\
824.17 \\
1348.33 \\
6224.47\end{array}$ & $\begin{array}{r}1853.83 \\
2044.49 \\
127.13 \\
1608.58 \\
137.36 \\
112.36 \\
62.87\end{array}$ & $\begin{array}{r}1.14 \\
40.47 \\
2.02 \\
25.59 \\
2.18 \\
1.79\end{array}$ & 柾玨 \\
\hline
\end{tabular}

Exceeds the 1 per cent level of stgniticance Ieast significant Disferences:

I.S.D. (Memperatures) $=(1.74)(2.447)=\frac{+}{+} .26$ degrees
I.S.D. (Varieties) $=(1.87)(1.987)= \pm .71$ degrees 

PPPTDIT V

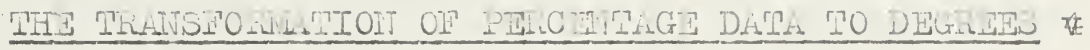

Percentage $=\sin ^{2} \theta$

Per cent Degrees Percent Degrees Per cent Desrees

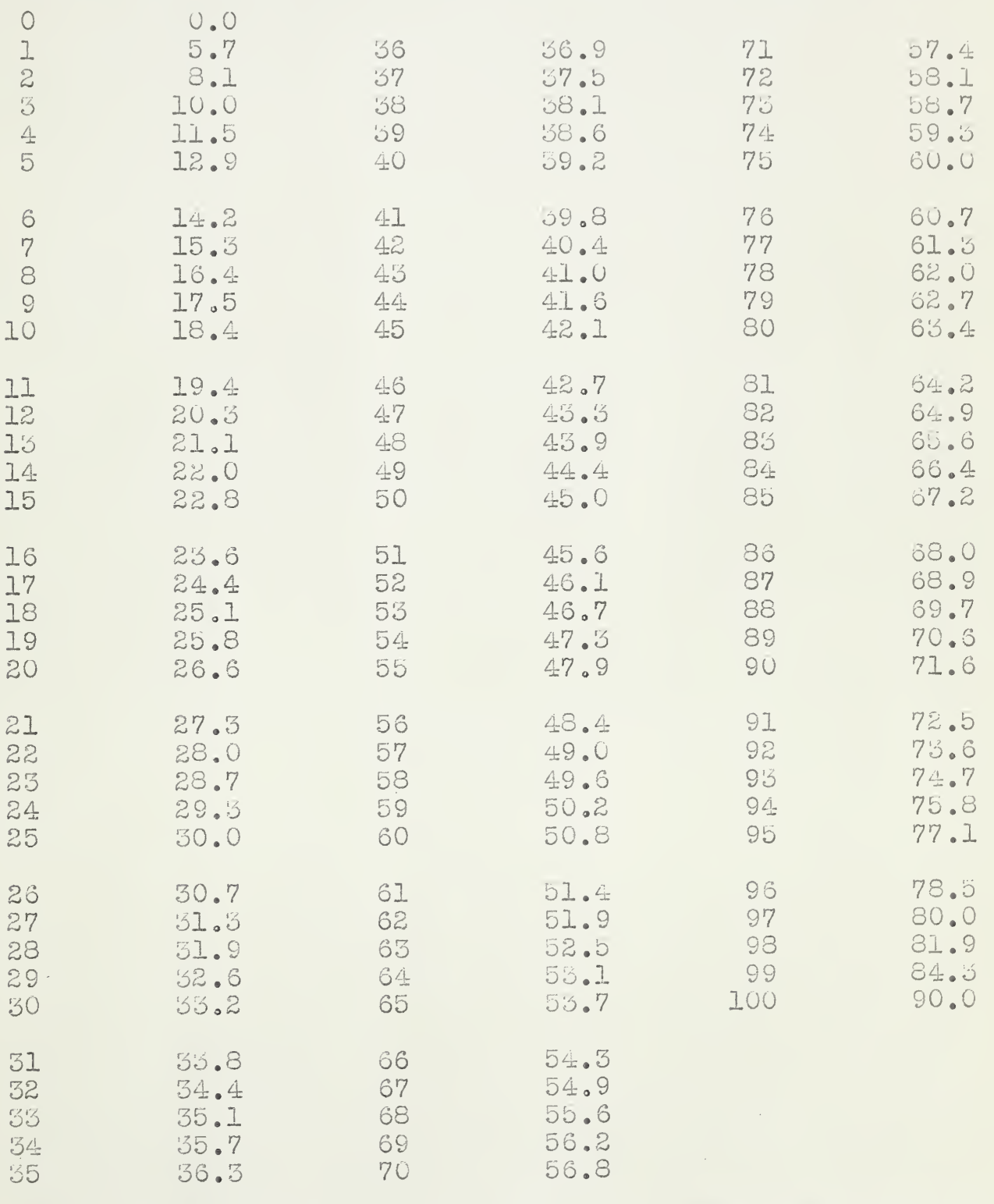







\section{B29765}

